\title{
Global Prosperity
}

International Scientifific e-Jourinal

\author{
Volume IIssule ?
}


Global Prosperity is an academic peerreviewed open-access e-journal. http://gprosperity.org/

\section{Editorial Board Chairman (Legal and} Technical Sciences):

L. Sopilnyk, D.Sc. (Law), D.Sc. (Technical Sciences), Professor (Ukraine) chairmanLS@gprosperity.org

\section{Editorial Board Chairman (Social} Sciences):

L. Yankovska, DSc, Professor (Ukraine) chairmanLY@gprosperity.org

Editor-in-Chief:

Koshovyi, B., PhD (Ukraine) editor@gprosperity.org

Editorial Board (link)

Founder:

Lviv University of Business and Law (Ukraine)

Kulparkivska, 99, 79021, Lviv http://www.lubp.com.ua business law@ukr.net

Publisher:

Oktan Print (Czech Republic)

5. května 1323/9, Praha 4, 14000. https://www.oktanprint.cz/ oktanprint@email.cz

All journal content is licensed under a Creative Commons BY 4.0 International license

\section{Global Prosperity}

\section{Volume 1 Issue 2}

2021

\section{CONTENT}

Azarian V. Method of Discreteness Substantiation of Qualitative Characteristics Testing during Iron Ore Raw Materials Extraction

Semchuk Zh., Koshovyi B., Kramar R. Youth Event Management Potential and Social Development in Changing World 11

Oke R.A., Adetola 0.0., Owoeye Y.T., Akemien N.N., Adaaja B.0., Bakpolor V.R., Murtala M.O. Socio-Economic and Medicinal Importance of Eucalyptus Trees: a Critical Review

Zelman L., Mykytenko 0. Features of Teaching Humanities in Higher Education Institutions for Future Specialists in Hotel and Restaurant Business and Tourism 23

Zavalna Zh., \& Starynskyi M. Contractual Delegation of Sovereignty in Supranational Entities 29

Type of publication: electronic

\section{Country of publication:}

Czech Republic 


\title{
METHOD OF DISCRETENESS SUBSTANTIATION OF QUALITATIVE CHARACTERISTICS TESTING DURING IRON ORE RAW MATERIALS EXTRACTION
}

\author{
Volodymyr Azarian ${ }^{1}$
}

Received: 2021-06-11

Accepted: 2021-07-02

DOI: http://doi.org/10.46489/gpj.2021-1-2-1

\begin{abstract}
The article aims to substantiate the periodicity of the definition of the maintenance of a valuable component in faces. Information about the content of the valuable component is necessary to comply with the requirements of the enrichment complex while ensuring the process of the total cargo flow formation. Traditionally, in iron ore quarries, technical control services measure the content of the valuable component every shift, but the testing period requires determination. We aimed to justify the period of testing the quality characteristics of iron ore. To achieve the aim, we explored the quarry № 3 of the PJSC "ArcelorMittal Kryvyi Rih" Mining Department based on the provisions of the mining theory and using mathematical modelling and mathematical statistics methods. We developed a method of substantiating the period of testing the qualitative characteristics of the faces, which we checked based on data from the existing enterprise. Using our method, we proved the possibility of increasing the test period without losing the necessary information about the iron content and without reducing the quality characteristics of the formed final ore flow. Increasing the test period will help companies decrease costs by reducing the number of visits of technical control specialists to test the quarry face. The proposed technique can be helpful to any mining company that supports the data collection and maintain the statistical database of measurements of the valuable component content.
\end{abstract}

Keywords: valuable component content, ore freight flow, iron ore quality management, mining industry, testing period

\footnotetext{
${ }^{1}$ Volodymyr Azarian, D.Sc. (Technical Sciences), Professor, Professor of Department of Opencast Mining, Kryvyi Rih National University, Pushkina Str., 37, Kryvyi Rih, 50000, Ukraine, astp165@ukr.net, ORCID: https://orcid.org/0000-0001-9045-509X
} 


\section{ВСТУП}

Формування загального рудопотоку із заданими показниками якості здійснюється на підставі розподілу обсягів видобутку між забоями 3 різними показниками вмісту корисного компоненту (Byzov, V.F., Vilkul, Ju.G., Maksimov, I.I., 1982). При розв'язанні шихтувального завдання першим припущенням $\epsilon$ те, що забої починають роботу одночасно та працюють всю зміну без зупинок. Другим припущенням $\epsilon$ константне значення вмісту корисного компонента в забої впродовж всієї зміни. Насправді, в реальних умовах за період виробничої зміни відбуваються суттєві відхилення від початкового розрахунку, які впливають на формування якісних характеристик загального інтегрованого рудопотоку та амплітуду їх коливань. Зумовлюються ці відхилення багатьма факторами: неодночасністю початку роботи по забоях, поломками устаткування та природною динамікою зміни вмісту корисного компонента в кожному видобувному забої. Для усунення дисбалансу між розрахунковими i фактичними значеннями якості необхідно періодично виконувати коригувальний перерахунок у шихтувальному завданні. Після цього навантаження на забої перерозподіляються 3 урахуванням поточного значення вмісту корисного компоненту та працездатності обладнання.

Фактичні значення вмісту корисного компоненту в кожному забої визначаються методами оперативного контролю. Для отримання своєчасної та достовірної інформації про стан якісних характеристик у забоях необхідно, 3 урахуванням динаміки зміни вмісту корисного компоненту, обгрунтувати інтервал опробування.

у залізорудних кар'єрах служби технічного контролю виконують опробування у забоях щозміни, використовуючи наявну апаратурну базу пристроїв. При цьому виходять, перш за все, з технічних можливостей цих пристроїв по контролю якості. Але сам період зняття інформації про вміст корисного компонента (дискретність опробування) - математично i технологічно не обгрунтований (Babij, E.V., Sinenko, M.A., 2010). Тому метою досліджень визначено розробку методики обгрунтування дискретності опробування якісних характеристик залізорудної сировини на основі існуючих статистичних даних. Визначений період опробування дозволить отримувати більш достовірну та своєчасну інформацію про фактичні значення вмісту корисного компонента в забоях, які в подальшому будуть використані для розрахунку змінно-добового завдання 3 метою формування загального інтегрованого рудопотоку 3 відповідними показниками якості.

Для обгрунтування дискретності опробування якісних характеристик залізорудної сировини в забоях 3 використанням статистичних даних було застосовано теорії гірничої справи, методи математичного моделювання, математичної статистики та графічний аналіз.

Для проведення розрахунку використовувались результати вимірів вмісту заліза магнітного в руді кар'єру № 3 Гірничого департаменту ПАТ «АрселорМіттал Кривий Ріг» екскаваторами №№ 56, 23 та 97.

\section{РЕЗУЛЬТАТИ}

Похибка вимірювання, як i особливості технологічних процесів при видобутку залізної руди, вказують на можливість обліку зміни вмісту корисного компоненту 3 визначеною дискретністю. Це приводить до висновку про можливість вимірювання якості в забоях з певним періодом, та 
розглядати рудний вантажопотік як дискретний часовий ряд.

Згідно із загальним підходом для чисельного аналізу вмісту корисного компонента в руді, виміри цього вмісту $\mathrm{c}(\mathrm{t})$, як безперервного в часі, необхідно здійснювати через деякий фіксований інтервал $\Delta$. Отримані таким чином дискретизовані значення будуть потім використовуватися для подальших обчислень змінно-добових завдань.

Дискретизовані значення можна розглядати як результат множення початкового безперервного часового ряду $\mathrm{c}(\mathrm{t})$ на часовий ряд $\mathrm{i}(\mathrm{t})$, що складається 3 нескінченної низки дельта-функцій (Rodionov, I.B., 2011):

де $\delta(t)=\left\{\begin{array}{ll}0, & t \neq 0 \\ \infty, & t=0\end{array}\right.$.

$$
i(t)=\sum_{n=-\infty}^{\infty} \delta(t-n \Delta),
$$

Це дає можливість відобразити корисного компонента в руді: імпульсно-модульований вміст

$$
c_{i}(t)=c(t) i(t) .
$$

Користуючись теоремою про формули (2) в частотній області: згортку, знаходимо подання

$$
C_{i}(f)=\int_{-\infty}^{\infty} C(f-g) I(g) d g,
$$

де $C(f), I(f)-$ перетворення Фур'є від $c(t)$ та ${ }^{i(t)}$, відповідно. Враховуючи, що

$$
I(g)=\frac{1}{\Delta} \sum_{n=-\infty}^{\infty} \delta\left(g-\frac{n}{\Delta}\right),
$$

формула (3) перетвориться до

вигляду

$$
C_{i}(f)=\int_{-\infty}^{\infty} C(f-g) \frac{1}{\Delta} \sum_{n=-\infty}^{\infty} \delta\left(g-\frac{n}{\Delta}\right) d g=\frac{1}{\Delta} \sum_{n=-\infty}^{\infty} C\left(f-\frac{n}{\Delta}\right) .
$$

Рівність (5) показує, що імпульсномодульований вміст корисного компонента в руді с (t) $\epsilon$ перетворенням

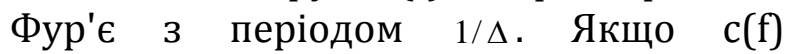
обертається на нуль при $|f| \geq 1 /(2 \Delta)$, то

$$
H(f)=\left\{\begin{array}{l}
\Delta,|f| \leq \frac{1}{2 \Delta} \\
0,|f|>\frac{1}{2 \Delta}
\end{array} .\right.
$$

Функція (6) є спектральним вікном і вона знаходиться, як перетворення

$$
h(t)=\frac{\Delta}{\pi \cdot t} \sin \left(\frac{\pi \cdot t}{\Delta}\right) .
$$

Так як множенню в частотній області відповідає згортка в часовій області, то, 3 урахуванням

$$
c(t)=\frac{\Delta}{\pi} \int_{-\infty}^{\infty} \frac{1}{u} \sin \left(\frac{\pi \cdot u}{\Delta}\right) \cdot c_{i}(t-u) d u .
$$

Частота $f_{N}=1 /(2 \Delta) \quad$ називається частотою Найквіста-Котельникова і $\epsilon$ найвищою частотою, яку можна виявити за даними, отриманими 3 інтервалом відліку $\Delta$. 
Для аналізу часового ряду, складеного 3 вмісту корисного компоненту в руді, 3 метою обгрунтування періоду вимірювання спектральні властивості цього ряду, що спираються на властивості якості у забоях кар'єру, треба дослідити

автокореляційної функції і нормованого спектра.

Відомо, що автокореляційна функція $є$ залежністю взаємозв'язку між функцією та їі здвигнутою копією від величини часового здвигу. Якщо автокореляційна функція оцінюється за формулою

$$
r_{k}=\frac{d_{k}}{d_{0}},
$$

де $d_{k}=\frac{1}{N} \sum_{i=1}^{N-k}\left(c_{i}-\bar{c}\right)\left(c_{i+k}-\bar{c}\right), \quad \bar{c}=\frac{1}{N} \sum_{i=1}^{N} c_{i}$, $k=0,1,2, \ldots, K$, то вибірковий нормований

$$
S(f)=2\left(1+2 \sum_{k=1}^{K-1} r_{k} \cos (2 \pi \cdot f \cdot k)\right), \quad 0 \leq f \leq 0,5
$$

Відомо, що вибірковий нормований спектр - це косинус-перетворення Фур'є вибіркової автокореляційної функції. Аналізуючи графік, побудований за допомогою вибіркового нормованого спектра (10), можна оцінити розподіл дисперсії часового ряду за частотами (Gmurman, V.E., 1975).
На рис. 1 наведено результати вимірів вмістів заліза магнітного в руді, що добувається в кар'єрі № 3 Гірничого департаменту ПАТ «АрселорМіттал Кривий Ріг» екскаваторами №№ 56, 23 та 97. Опробування видобувних забоїв виконувалися зі стандартним інтервалом у 12 годин.

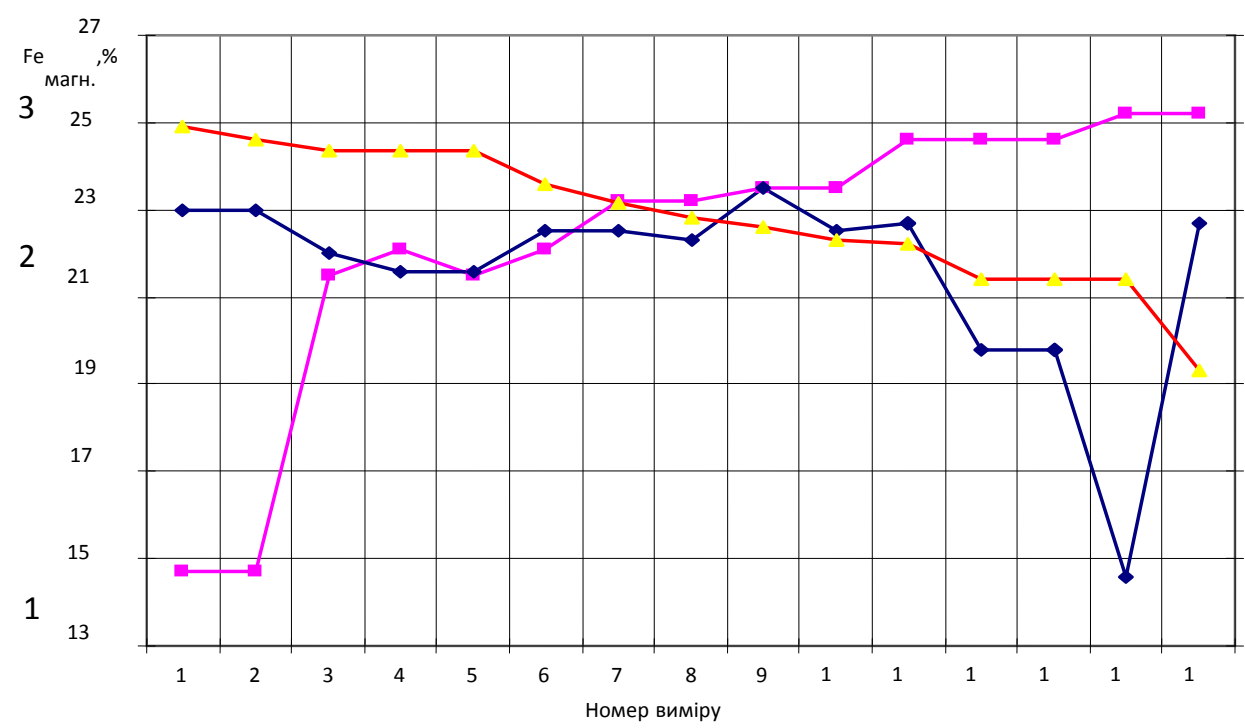

Рис. 1. Результати вимірів вмісту Fе маг., \% в кар’ері № 3 Гірничого департаменту

ПАТ «АрселорМіттал Кривий Ріг»: 1 - екскаватор № 56, 2 - екскаватор № 23, 3 - екскаватор № 97

Якщо значення дисперсії будуть сконцентровані на низьких частотах, що менші за частоти НайквістаКотельникова $f_{N}$, то дискретність опробування можна збільшити.

Розглянемо приклад обгрунтування періоду опробування забоїв кар'єру на підставі наявної статистики вимірів вмісту корисного компоненту кар'єру № 3 Гірничого департаменту ПАТ «АрселорМіттал Кривий Ріг».

У табл. 1 наведені значення вибіркових автокореляційних функцій, розрахованих за формулою (9) для забоїв екскаваторів №№ 56, 23 та 97 
кар’єру № 3 Гірничого департаменту

ПАТ «АрселорМіттал Кривий Ріг».

Таблиця 1

Значення вибіркових автокореляційних функций Аля забоїв екскаваторів №№ 56, 23 та 97 кар’єру № 3 Гірничого департаменту ПАТ «АрселорМіттал Кривий Ріг»

\begin{tabular}{|c|c|c|c|}
\hline $\begin{array}{c}\text { № } \\
\text { екскаватора }\end{array}$ & 93 & 56 & 23 \\
\hline 1 & 0,67 & 0,57 & 0,73 \\
\hline 2 & 0,41 & 0,42 & 0,51 \\
\hline 3 & 0,37 & 0,42 & 0,36 \\
\hline 4 & 0,15 & 0,34 & 0,19 \\
\hline 5 & 0,04 & 0,33 & 0,21 \\
\hline 6 & $-0,21$ & 0,43 & 0,20 \\
\hline 7 & -0.24 & 0,50 & 0,04 \\
\hline
\end{tabular}

На рис. 2, 3 та 4 наведено графіки вибіркових автокореляційних функцій вмісту заліза магнітного в забоях

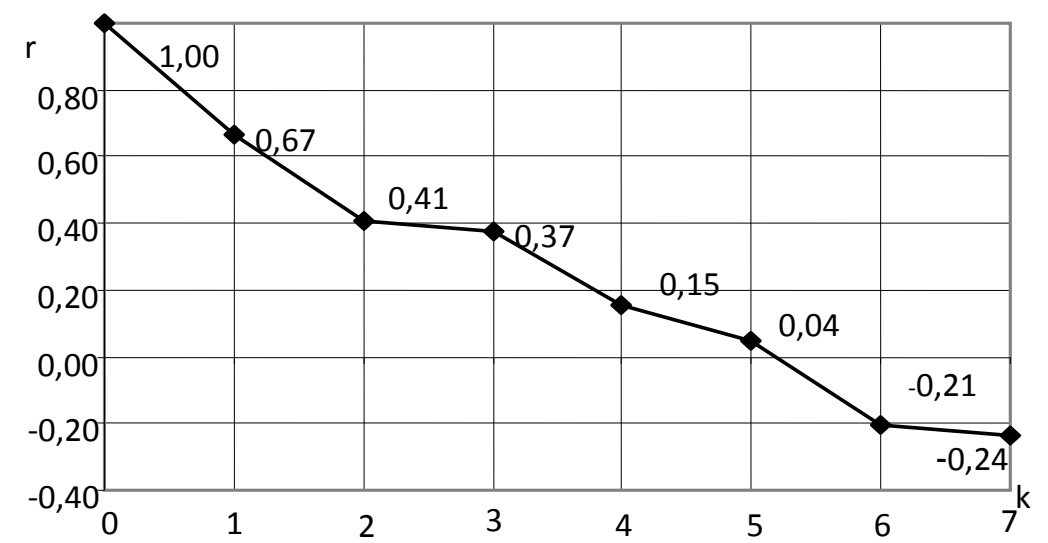

Рис. 2. Вибіркова автокоремяційна функція вмісту заліза магнітного в забої екскаватору № 93

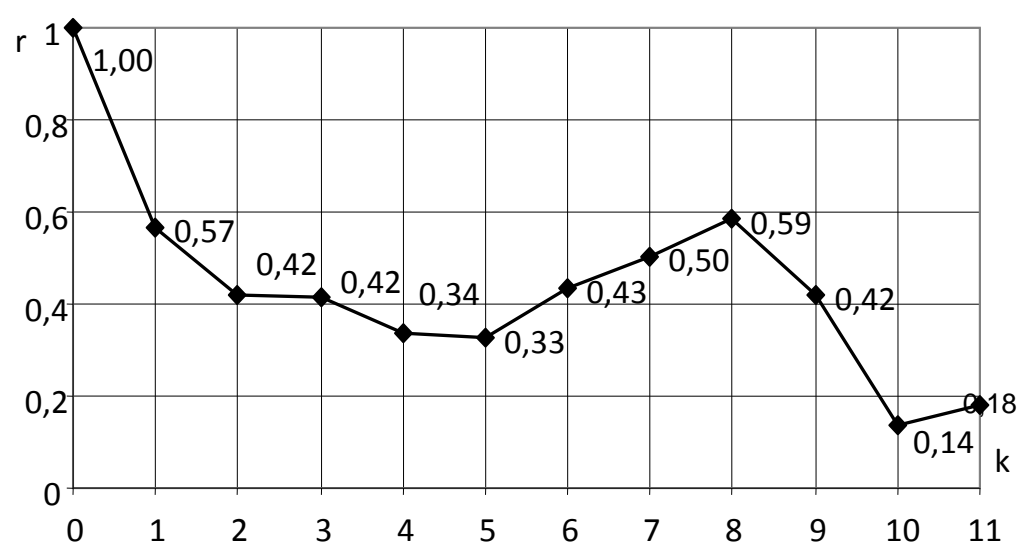

Рис. 3. Вибіркова автокоремяційна функція вмісту заліза магнітного в забої екскаватору № 56 


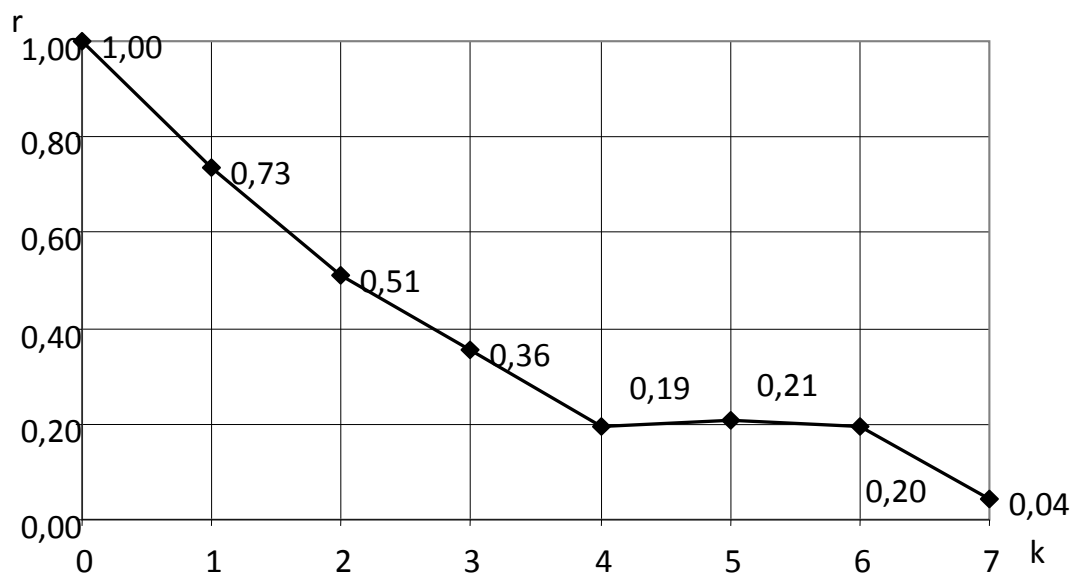

Рис. 4. Вибіркова автокоремяційна функція вмісту заліза магнітного в забої екскаватору № 23

В табл. 2 наведено значення вибіркових нормованих спектрів, що розраховані за формулою (10) на основі даних табл. 2.

Таблиця 2

Значення вибіркових нормованих спектрів

\begin{tabular}{|c|c|c|c|}
\hline $\begin{array}{c}\text { № } \\
\text { екскаватора }\end{array}$ & 93 & 56 & 23 \\
\hline 0 & 6,76 & 19,31 & 10,97 \\
\hline 0,1 & 4,548 & 2,62 & 2,41 \\
\hline 0,2 & 1,167 & 0,03 & 1,29 \\
\hline 0,3 & 0,032 & 0,45 & 0,38 \\
\hline 0,4 & 0,853 & 0,00 & 0,32 \\
\hline 0,5 & 0,04 & 0,00 & 0,23 \\
\hline
\end{tabular}

Аналіз вибіркових нормованих спектрів, який буде виконано далі, дозволить зробити висновки про те, на яких частотах і як концентрується дисперсія рядів, що досліджуються.

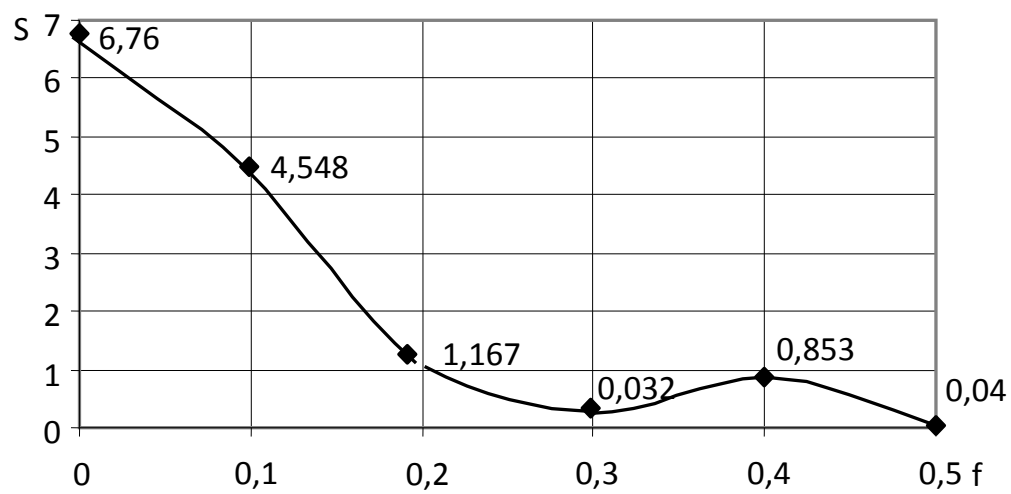

Рис. 5. Вибірковий нормований спектр вмісту заміза магнітного в забої екскаватору № 93 
Графічний аналіз вибіркових нормованих спектрів, що представлені на рис. 5, 6 та 7, дозволяє зробити висновок, що дисперсія досліджуваних рядів концентрується в основному на низьких частотах, а саме - від 0 до 0,3.
В подальшому, при використанні даної методики, зона концентрація дисперсії приймається як найбільш доцільна для аналізу.

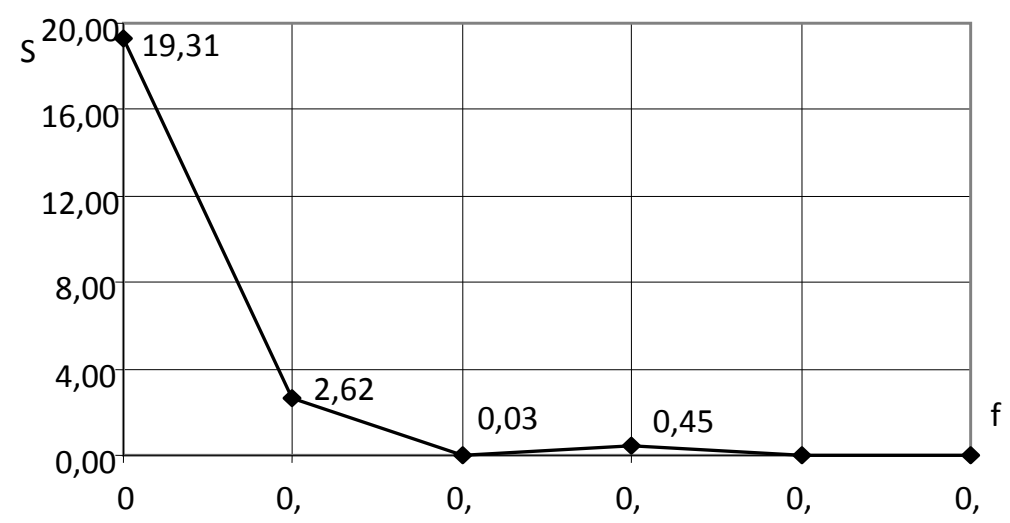

Рис. 6. Вибірковий нормований спектр вмісту заміза магнітного в забої екскаватору № 56

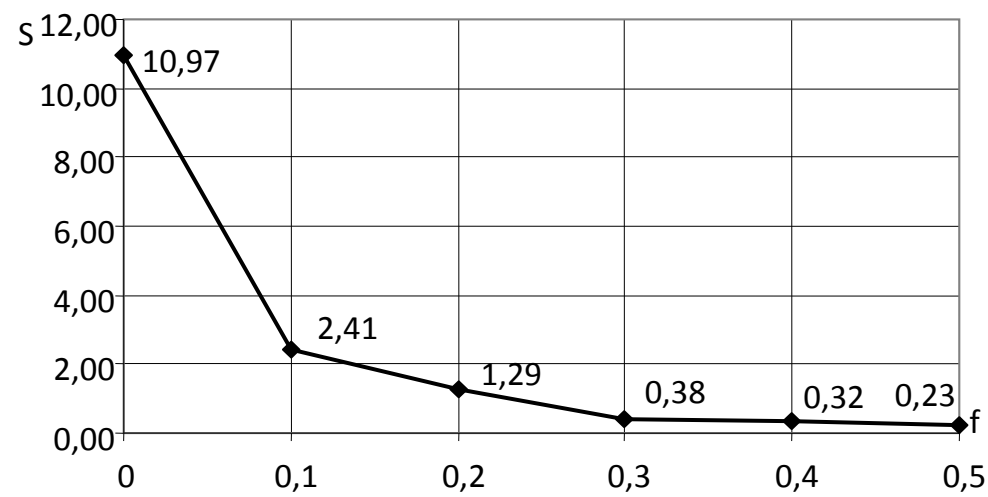

Рис. 7. Вибірковий нормований спектр вмісту заміза магнітного в забої екскаватору № 23

Таким чином, для можливості виділення частот, що пов'язані зі зміною вмісту заліза в руді, досить вибрати частоту $f=0,3 / \Delta$, або позначити період

$$
T=\frac{10 \cdot \Delta}{3}
$$

Спираючись на те, що згідно 3 існуючою дискретністю вимірюванням у забоях вмісту заліза магнітного в руді, які здійснюються з інтервалом 12 годин, отримуємо можливість математично

$$
T=\frac{10 \cdot 12}{3}=40 \text { годин }
$$

Отримане значення періоду опробування якості у видобувних отримання інформації про вміст корисного компонента в забоях кар'єру у наступному вигляді: забоїв, що дозволить розрізняти максимальні частоти зміни вмісту корисного компоненту: 
ніж у три рази без втрати необхідної інформації про динаміку зміни вмісту корисного компонента.

Наявність такої інформації дозволить формувати загальний інтегрований рудний вантажопотік кар'єру 3 потрібними показниками якості, що вплине на показники прибутку гірничовидобувного підприємства [5].

Слід зазначити, що з точки зору математичної статистики, чим за більший період буде застосовані дані про розподіл якості у забоях, тим вірогіднішим буде розрахунок періоду вимірювання. Враховуючи стохастичний характер розподілу якості в межах родовища, доцільно проводити уточнюючи розрахунки, тому що 3 підвищенням коливань вмісту корисного компоненту в забоях період опробування буде скорочуватися.

Дану методику може бути застосовано на всіх залізорудних підприємствах, де $\epsilon$ відповідний статистичний матеріал про вміст

\section{References}

Byzov, V.F., Vilkul, Ju.G., Maksimov, I.I. (1982). Ob usrednenii kachestva rud pri ob\#edinenii

Metallurgicheskaja promyshlennost', 2, 64-65. gruzopotokov.

Babij, E.V., Sinenko, M.A. (2010). O kachestve rudnogo potoka pri tehnologi predobogashhenija rudy v kar'ere. Visnyk Kryvorizkoho natsionalnoho universytetu, 25, 3-8. корисного компонента у видобувних забоях за певний період вимірювань.

\section{ВИСНОВКИ}

1. Запропонована

методика обгрунтування опробування якісних характеристик залізорудної сировини дозволяє обгрунтовано визначити період проведення вимірів вмісту корисного компоненту у забоях.

2. Розрахунками на прикладі кар'єру № 3 Гірничого департаменту ПАТ «АрселорМіттал Кривий Ріг» доведено можливість збільшення періоду опробування без втрати необхідної інформації про вміст заліза та без зниження якісних характеристик сформованого фінального рудопотоку.

3. Зміна періоду опробування у бік збільшення дозволить знизити витрати підприємства, зменшуючи кількість рейсів фахівців відділу технічного контролю на опробування забоїв кар'єру.

Rodionov, I.B. (2011). Teorija i sistemnyj analiz, Retrived from http://eidos.ru/journal/1998/0781.htm.

Gmurman, V.E. (1975). Rukovodstvo k resheniju zadach po teorii verojatnostej i matematicheskoj statistike. Moskva: Vysshaja shkola

Azarjan, V.A. (2015). Issledovanie vlijanija kachestva rudopotoka zhelezorudnogo kar'era na pribyl' gornoobogatitel'nogo kombinata. Hirnychyi visnyk, 100, 58-62 


\title{
YOUTH EVENT MANAGEMENT POTENTIAL AND SOCIAL DEVELOPMENT IN CHANGING WORLD*
}

\author{
Zhanna Semchuk ${ }^{1}$, Bohdan Koshovyi ${ }^{2}$, Ruslana Kramar ${ }^{3}$
}

Received: 2021-06-04

Accepted: 2021-07-04

DOI: http://doi.org/10.46489/gpj.2021-1-2-2

Abstract. In this article, we have considered the complex problem of developing and realizing the potential of young people in the light of the challenges that arise in the modern world. Young people are a vulnerable social group for whom state and local support is essential. Problems in employment can shake the incentive for young people to develop their potential. We investigated the impact of educational and social space on the development of one of the components of youth potential - potential in event management. We emphasized that the development of this component can be a good impetus for intensifying the entrepreneurial activity of young people. However, youth employment and entrepreneurship in event management need care from the state and intensification of informal social control mechanisms. We have formed recommendations that will allow integrating the processes of social development and development of youth potential in event management. This work can be helpful for public authorities, educational institutions and public organizations.

Keywords: youth, potential, development of potential, event management potential, social control.

\footnotetext{
${ }^{*}$ To prevent conflicts of interest, the Chairman of the Editorial Board managed the entire editorial process for this article according to the ethical standards of Global Prosperity (http://gprosperity.org/index.php/journal/pol)

1 Zhanna Semchuk, D. Sc. (Economics), Professor, Dean of the Faculty of Economics and Business, Lviv University of Business and Law, Kulparkivska str., 99, Lviv, Ukraine, ORCID: https://orcid.org/0000-0002-4868-7716

2 Bohdan-Petro Koshovyi, PhD, Head of the Department of Demography, Labor Relations and Social Policy, Lviv University of Business and Law, Kulparkivska str., 99, Lviv, Ukraine, qqbkqq@gmail.com, ORCID: https://orcid.org/0000-0001-8550-0028

3 Ruslana Kramar, PhD, Associate Professor, Head of the Department of Judiciary, Prosecutory and Advocacy, Lviv University of Business and Law, Kulparkivska str., 99, Lviv, Ukraine, ORCID: http://orcid.org/0000-00015086-9845
} 


\section{ВСТУП}

Особливе місце у системі управління соціальним розвитком належить підсистемі управління соціальним розвитком молоді.

Молодь $\epsilon \quad$ специфічною демографічною групою, що об’єктивно обмежується рамками переходу від стану дитячої залежності до дорослої незалежності (Резолюції Генеральної асамблеї $\quad \mathrm{OOH} \quad \mathrm{A} / \mathrm{RES} / 50 / 81$, A/RES/56/117, A/RES/62/126). Відповідно, динаміка соціального розвитку молоді поступово (а іноді стрімко) виходить з-під контролю батьків чи опікунів і опиняється $\mathrm{y}$ залежності від особистісних характеристик молодої особи. Таким чином, відповідальність за вирівнювання динаміки соціального розвитку молоді має взяти на себе держава як інститут найвищого авторитету. Ефективність державної політики за цим напрямком визначає вихідну позицію соціального розвитку дорослої особи, здобуту унаслідок попереднього розвитку у процесі їі становлення в рамках належності до групи молоді.

\section{Демографічна} характеризується потребами (освіта, охорона здоров'я (зокрема, у сфері дітонародження, здорового харчування, попередження шкідливих звичок), безпека (у зв'язку з підвищеними ризиками девіантної та деліквентної поведінки), житло, духовні потреби, розваги тощо). У зв'язку 3 переважно недостатнім фінансовим забезпеченням, у повній мірі задовольнити потреби молоді, необхідні для подальшого соціального розвитку, може тільки держава.

Молодь $\epsilon$ ключовим об'єктом управлінських впливів у сфері формування трудового потенціалу. Основа подальшої трудової діяльності більшості дорослого населення закладається у молодіжному віці. Ефективність соціального розвитку у частині формування трудового потенціалу молоді слід оцінювати також крізь призму здатності держави забезпечити молодих фахівців гідним місцем праці і таким чином уникнути невиправдної трудової міграції.

Проголошений соціальний характер української економіки доповнюється традиційним для України культурним феноменом спадковості поколінь концентрація зусиль на розвитку молоді означає здатність молоді у подальшому брати участь у утриманні громадян, котрі досягли пенсійного віку, у фінансуванні розвитку нового покоління молоді і впевненість у майбутньому захисті по досягненню пенсійного віку.

За умови ефективної побудови i функціонування системи соціального розвитку молоді, молодь проявляє себе як рушій суспільних, економічних, політичних перетворень завдяки такій особливій властивості як готовність і відкритість до змін, інноваційне мислення, висока творча i трудова активність.

Одним 3 елементів трудового потенціалу молоді $є$ потенціал у сфері івент-менеджменту. Вибудування соціальних зв'язків молоді на основі цього елементу трудового потенціалу $\epsilon$ передумовою забезпечення сталого економічного і соціального розвитку. Централізована i децентралізована промоція програм з розвитку розуміння i використання навичок івентменеджменту у молоді дозволить досягнути європейських стандартів у сфері соціального розвитку молоді та стане запорукою інтеграції у європейський економічний, освітній та культурний простір.

Метою статmі $є$ обгрунтувати теоретичні засади розвитку і реалізації потенціалу молоді у сфері івентменеджменту. 


\section{РЕЗУЛЬТАТИ}

Станом на сьогодні у сфері регулювання молодіжної зайнятості в Україні спостерігаються значні труднощі, пов'язані не лише 3 проблемами економічного чи політичного характеру, але і 3 недосконалістю методологічних підходів. Bondarevska K. V., Fomenko A. O. (2015) грунтовно дослідили актуальні проблеми молодіжної зайнятості в сучасних умовах і встановили, що пріоритетними проблемами щодо зайнятості молоді, які потребують свого вирішення, $є$ подолання дисбалансу на ринку праці; створення нових робочих місць; досягнення порозуміння між державою, роботодавцями та молодими фахівцями.

Молодь $\epsilon$ уразливою соціальною групою, для неї недоступні певні уміння та навички, які приходять з досвідом. Безперечно, у окремих випадках спостерігаються особи, котрі володіють природженим організаторським хистом та мають природній потенціал у сфері івент-менеджменту, реалізація якого дозволяє без додаткової підготовки вирішити проблеми 3 працевлаштуванням.

Сучасні процеси реформування вищої освіти в Україні скеровуються на досягнення такого рівня якості освіти, за якого здобуті у ході навчання компетенції, у тому числі у сфері івентменеджменту відповідатимуть вимогам роботодавців. Вища освіта - це сукупність систематизованих знань, умінь і практичних навичок, способів мислення, професійних, світоглядних i громадянських якостей, моральноетичних цінностей, інших компетентностей, здобутих у вищому навчальному закладі (науковій установі) у відповідній галузі знань за певною кваліфікацією на рівнях вищої освіти, що за складністю є вищими, ніж рівень повної загальної середньої освіти. Водночас, компетентність визначається як динамічна комбінація знань, вмінь i практичних навичок, способів мислення, професійних, світоглядних і громадянських якостей, морально-етичних цінностей, яка визначає здатність особи успішно здійснювати професійну та подальшу навчальну діяльність і $\epsilon$ результатом навчання на певному рівні вищої освіти (Zakon Ukrainy «Pro vyshchu osvitu»).

3 успішністю подальшої професійної діяльності пов'язуються також терміни «якість вищої освіти» та «результати навчання». Так, якість вищої освіти - це рівень здобутих особою знань, умінь, навичок, інших компетентностей, що відображає її компетентність відповідно до стандартів вищої освіти; результати навчання - це сукупність знань, умінь, навичок, інших компетентностей, набутих особою у процесі навчання за певною освітньо-професійною, освітньо-науковою програмою, які можна ідентифікувати, кількісно оцінити та виміряти. Водночас, на нашу думку, 3 позиції забезпечення подальшої професійної діяльності слід по-іншому трактувати процес здобуття освіти (не тільки вищої). Керуючись спостереженнями за суспільними трендами, інтерв'юванням студентів різних спеціальностей можемо висловити гіпотезу щодо важливості у рамках вищої освіти формування не «компетентностей», а трудового потенціалу молоді, у тому числі й за окремими напрямками, як-от івентменеджмент.

Молодь віком 15 - 24 р. нерідко потребує особливої підтримки щодо першого працевлаштування. Не володіючи досвідом роботи, утім маючи суттєвий потенціал до праці (трудовий потенціал) нерідко молодь у цьому віці стає жертвами «тіньової економіки» працевлаштування на неформальних засадах (без офіційного оформлення). Особливо уразливою $є$ група молоді, котра прагне реалізувати потенціал у сфері івент-менеджменту. Оскільки це відносно нова галузь зайнятості, 
спостерігається брак нормативноправового забезпечення іiї регулювання, що може негативно позначитись на соціальному розвитку та захисті молоді.

В умовах обмеженості ресурсів можливості держави 3 покращення становища молоді $€$ досить обмежені. Утім, слід проводити постійну роботу 3 пошуку нових шляхів підвищення якості життя не зважаючи на складну ситуацію. Соціально-економічна криза, що розгорнулась в Україні, особливо відображається на молоді перетворившись для цієї групи у перманентну кризу. Слід відзначити, що основними напрямками покращення якості життя молоді за категорією фінансових потреб слід вважати стимулювання підприємницької діяльності молоді, завдяки якій уможливиться й реалізація та розвиток потенціалу у сфері івент-менеджменту

Dmytrash O. P., Smyrychynskyi V. V. (2009) наголошують, що в Україні виникла об'єктивна необхідність розробки ефективних механізмів, які б стимулювали працевлаштування молоді i сприяли б розвитку молодіжних підприємницьких ініціатив, що повинно знайти відображення у державній та регіональній молодіжній політиці. Зокрема, на думку науковців, доцільно фінансувати молодіжні програми за рахунок бюджетів усіх рівнів та проводити конкурси програм, на державному рівні прогнозувати потреби ринку у кваліфікованих спеціалістах та реалізовувати програми розвитку молодіжного підприємництва.

Як ми уже згадували, нормативноправове забезпечення містить прогалину у частині соціального контролю за функціонуванням системи управління соціальним розвитком молоді, що ускладнює формування єдиної системи розвитку потенціалу у сфері івентменеджменту.

Kondov K. V. (2011) з приводу актуальності проблематики соціального контролю слушно зауважує:
«Найважливішою умовою соціальної взаємодії та ефективного функціонування соціальної системи $€$ передбачуваність у діях та поведінці індивідів. Відсутність передбачуваності веде соціальну спільноту до дезорганізації та розпаду. Тому суспільством створюються механізми соціального контролю, які повинні регламентувати та консолідувати діяльність усіх його соціальних суб`єктів, забезпечуючи його стійке, стабільне функціонування, соціальний розвиток та прогрес». На думку Palchenkova V. M. (2015), соціальний контроль - це механізм, за допомогою якого суспільство та його складові елементи (групи, організації) забезпечує дотримання певних умов (обмежень), порушення яких завдає збитків функціонуванню соціальної системи.

У понятті соціального контролю спостерігається поєднання концепцій цілеспрямованого впливу керуючої системи на керовану, а також самоорганізації. Khyzhniak O. V. (2015) локальний соціальний контроль розглядає у якості механізму самоорганізації і самозбереження колективного суб'єкта шляхом встановлення, відтворення в процесі колективної діяльності певного нормативного.

Існує значне розмаїття у визначенні підходів до формування механізмів соціального контролю. Daudova H. V. (2014) зауважує, що більш-менш значуща громадська участь вимагає високого ступеня децентралізації владних і адміністративних повноважень. Децентралізація, на думку вченої, $\epsilon$ однозначно необхідною умовою для громадської участі. Громадська участь може реалізовуватися шляхом прямого контакту громадянина з посадовими особами та за допомогою створення «груп інтересів.

Отже, механізм соціального контролю, як складова системи управління соціальним розвитком молоді може трактуватись у двох аспектах. 3 одного боку - це інституційний формальний механізм, у рамках якого керуюча підсистема (повноважний орган державної влади чи місцевого самоврядування, організації соціальної сфери) здійснює вплив на керовану соціальну підсистему методами соціального впливу для досягнення 
наперед визначених показників соціального розвитку. 3 іншого боку - це неформальна система, у рамках якої зацікавлена частина суспільства (соціальна група) здійснює у визначених законом рамках контроль за динамікою соціального розвитку на засадах самоорганізації. Досягнення високих темпів соціального розвитку молоді вимагає узгодження, гармонізації обох систем. Демократизація суспільства та децентралізація владних повноважень, високий рівень розвитку інформаційних технологій зумовлюють актуальність стимулювання саме другого типу соціального контролю як найбільш ефективного.

Ефективність інституційного соціального контролю у системі управління соціальним розвитком молоді, зокрема, розвитку потенціалу у сфері івентменеджменту, обмежується низкою чинників:

- обмеженість ресурсів (фінансовоматеріальних, кадрових, часу та ін..);

- відсутність мотивації поглибленого вивчення проблем соціального розвитку поза рамками нормативно встановлених пріоритетів та напрямів;

- низька гнучкість у зв'язку з вимушеною діяльністю у рамках нормативних приписів, що не завжди відповідають вимогам часу;

- недостатня готовність використання усього потенціалу сучасних інформаційних технологій;

- $\quad$ комунікативні перешкоди - труднощі у налагодженні комунікацій між об’єктом та суб'єктом управлінського впливу.

Водночас, забезпечення формування i реалізації механізмів неформального соціального контролю вимагає державної підтримки, що може бути реалізована у вигляді:

- грантів, конкурсів на реалізацію проектів соціального контролю у сфері управління соціальним розвитком молоді;

- налагодження міжнародних зв'язків та обміну досвідом 3 державами, де неформальний соціальний контроль $є$ потужним інструментом підвищення ефективності соціального розвитку;
- стимулювання взаємодії державних наукових та освітніх установ, організацій соціальної сфери і недержавних громадських організацій щодо удосконалення методології соціального контролю;

- інформаційна, кадрова, фінансова підтримка (на засадах невтручання та забезпечення незалежності) недержавних громадських організацій, що здійснюють соціальний контроль у системі управління соціальним розвитком;

- забезпечення реалізації правових, політичних, економічних реформ на основі рекомендацій, одержаних 3 незалежних джерел сформованих на основі діяльності суб'єктів неформального соціального контролю.

\section{ВИСНОВКИ}

Проблема соціального розвитку молоді, зокрема, за різними напрямками розвитку потенціалу, традиційно зберігає свою актуальність і у наш час. Конкуренція держав в умовах процесів глобалізації переходить з економічної у соціальну площину. Забезпечення високих макроекономічних показників вже не може вважатись винятковим показником ефективності державної політики. Зміщення парадигми розвитку з економічної у соціальну площину відповідає вимогам часу, гуманістичній, антропоцентричній політиці, що системно проводиться найбільш розвиненими державами cвiтy.

В силу низької поширеності концепцій соціальної відповідальності підприємств на нинішньому етапі в Україні неможлива відмова від державного регулювання процесів, пов'язаних 3 забезпеченням якості життя молоді та розвитку їі потенціалу, зокрема, у сфері івент-менеджменту. Особливо небезпечними загрози, пов'язані з низькою якістю життя є для молоді. Молодь, опиняючись в умовах кризової економіки часто втрачає надію на покращення своїх побутовоматеріальних умов, виїжджає за кордон 
або працевлаштовується у неформальному секторі економіки. Потенціал молоді виявляється розпорошений, незадіяний у процесах виходу економіки 3 кризи та їі прискореного розвитку.

Практичні кроки 3 забезпечення соціального розвитку молоді реалізуються у рамках різноманітних державних

\section{References}

Bondarevska K. V., Fomenko A. O. (2015). Aktualni problemy molodizhnoi zainiatosti v suchasnykh umovakh. Stalyi rozvytok ekonomiky, 1. 110-115. Retrieved from:

http://nbuv.gov.ua/UJRN/sre_2015_1_18

Daudova H. V. (2014). Sotsialnyi kontrol nad diialnistiu orhaniv vlady: polityko-upravlinskyi aspekt. Aktualni problemy derzhavnoho upravlinnia, 1. 156163.

Dmytrash O. P., Smyrychynskyi V. V. (2009). Problemy rozvytku molodizhnoho innovatsiinoho pidpryiemnytstva v Ukraini. Problemy nauky, 2. 10-16.

Khyzhniak O. V. (2015). Lokalnyi sotsialnyi kontrol yak kolektyvna diia (na prykladi kolektyvno-dohovirnoi praktyky). Mizhnarodnyi naukovyi forum: sotsiolohiia, psykholohiia, pedahohika, menedzhment, 18. 21-30.

Kondov K. V. (2011). Sotsialnyi kontrol, yak sotsialnyi fenomen: porivnialna kharakterystyka sotsiolohichnykh нормативно-правових актів і програм, міжнародних програм, грантів тощо. Утім, рівень динаміки соціального розвитку в Україні не відповідає потребам часу, євроінтеграційним прагненням нашої держави. Одним 3 дієвих напрямків підвищення ефективності системи управління соціальним розвитком молоді $\epsilon$ удосконалення механізмів контролю.

pidkhodiv. Hrani: Naukovo-teoretychnyi i hromadsko-politychnyi almanakh, 1. S. 104-109.

Kondov K.V. (2010). Sotsialnyi kontrol yak umova efektyvnoho funktsionuvannia instytutu osvity. Aktualni problemy sotsiolohii, psykholohii, pedahohiky: Zbirnyk naukovykh prats, 11. 149-155

Palchenkova V. M. (2015). Kontseptsiia sotsialnoho kontroliu $\mathrm{V}$ suchasnii teoretyko-pravovii nautsi. Yurydychna nauka, 8. 7-14.

Riven bezrobittia naselennia (za metodolohiieiu MOP) za stattiu, vikovymy hrupamy ta mistsem prozhyvannia. Retrieved from: http://www.ukrstat.gov.ua/operativ/oper ativ2015/rp/eans/eans_u/rbrn_rik15_u.ht $\mathrm{m}$

Zakon Ukrainy «Pro vyshchu osvitu» Retrieved from: http://zakon2.rada.gov.ua/laws/show/15 56-18 


\section{SOCIO-ECONOMIC AND MEDICINAL IMPORTANCE OF EUCALYPTUS TREES: A CRITICAL REVIEW}

Oke R.A. ${ }^{1}$, Adetola O.O. ${ }^{2}$, Owoeye Y.T. ${ }^{3}$, Akemien N.N. ${ }^{4}$, Adaaja B.O. ${ }^{5}$, Bakpolor V.R. ${ }^{6}$, Murtala M.O. ${ }^{7}$

Received: 2021-06-09

Accepted: 2021-07-06

DOI: http://doi.org/10.46489/gpj.2021-1-2-3

Abstract. Pollution is a great issue of the environment that is gaining global attention currently because industrial development has disturbed the ecosystem of the world and depleting the ozone. It has resulted in global warming and increased the temperature, which has changed the climate at different levels globally. According to a world report, about $25 \%$ of forest land is required for ecosystem favourability. There are so many trees which are grown in the world. Among these trees, Eucalyptus is very popular and was first grown in Australia. This plant has both economic and health benefits. Pharmacologists converted this plant into medicine for different health disease control in the world. Essential Oil squeezed from the leaf and bark of the tree and leaves also possess great benefits. The well-known diseases are blood pressure, diabetes, Arthritis, plague, Cough etc., while it is also used for mosquitoes, termites, and white ants control. The plant also has its disadvantage; it decreases the water table and disturbs the tube well system. Those plants need much water, so they compete with other plants in the area and affect the size of the plant. The major objective was to review the socioeconomic and medicinal value of the eucalyptus tree. Total 19 articles were downloaded from the net and reviewed in depth. The result indicates that the Eucalyptus tree has many socioeconomic and medicinal values.

Keywords: ecosystem disturbance, ecosystem favourability, Eucalyptus, Essential Oil, value of the eucalyptus tree.

\footnotetext{
${ }^{1}$ Oke R.A., Forestry Research Institute of Nigeria, P.M.B 5054 Jericho Hills, Ibadan, Nigeria, ORCID: https://orcid.org/0000-0003-0129-0145

${ }^{2}$ Adetola O.O., Forestry Research Institute of Nigeria, P.M.B 5054 Jericho Hills, Ibadan, Nigeria, e-mail: ajibols03@hmail.com, ORCID: https://orcid.org/0000-0002-4011-2686

${ }^{3}$ Owoeye Y.T., Forestry Research Institute of Nigeria, P.M.B 5054 Jericho Hills, Ibadan, Nigeria, ORCID: https://orcid.org/0000-0003-3049-9829

${ }^{4}$ Akemien N.N., Forestry Research Institute of Nigeria, P.M.B 5054 Jericho Hills, Ibadan, Nigeria, ORCID: https://orcid.org/0000-0002-3878-3210

${ }^{5}$ Adaaja B.O., Forestry Research Institute of Nigeria, P.M.B 5054 Jericho Hills, Ibadan, Nigeria, ORCID: https://orcid.org/0000-0002-9373-6329

${ }^{6}$ Bakpolor V.R., Forestry Research Institute of Nigeria, P.M.B 5054 Jericho Hills, Ibadan, Nigeria, ORCID: https://orcid.org/0000-0001-7098-2108

${ }^{7}$ Murtala M.O., Forestry Research Institute of Nigeria, P.M.B 5054 Jericho Hills, Ibadan, Nigeria, ORCID: https://orcid.org/0000-0001-8473-0622
} 


\section{INTRODUCTION}

Eucalyptus is a popular plant that is used for a different purposes. As a medicine, we used it for different ailments besides its economic value. Several Farmers grow this plant mostly in waterlogged areas. We primarily use the wood of the eucalyptus in the furniture industries because of a shortage of poplar wood in the world. Its wood is tough and patchy, and the farmer mainly used for fuelwood, while this wood is also used in the furniture industry. Their charcoals are commonly used and give more energy to them than the poplar wood. They mostly used this plant for the control of waterlogging. They are mostly planted on high $\mathrm{Ph}$ value soil. Shechem was replaced by eucalyptus because of a white ant attack. The majority of Shechem are observed on the river, which the white ant damaged. By canal irrigation, white ants were spread into farmland, and it destroys the crops and other plants of the farming community. Among this poplar plant is the sugar cane crop known in several parts of the globe. In some places, the sugarcane crop has been removed from the cropping pattern. The wood of the eucalyptus is also used as an electrical pole in the world.

They naturally found a few species in the Philippines, Papua New Guinea, Indonesia and Timor. Several ecological conditions support the growth of Eucalyptus, some hardy species growing in semi-arid areas, while others can grow on marshy and swampy sites. Eucalypts also grow under various soils, including fertile loamy soils, infertile sands and heavy clays (Boland et al., 2006). The population pressure in Ethiopian highlands and other parts of Africa has led to a change in land use or land cover and establishment of woodlots, so plantation of exotic tree species such as Eucalyptus has long been advocated as a strategy for relieving pressure on indigenous forests and woodlands (Boland et al., 2006). The eucalyptus tree has provided foresters and farmers with a valuable resource of fastgrowing species that can grow under a wide range of conditions based on the particular species being used. Factors that drive farmers to plant Eucalyptus include increasing demand for wood products in the market, unavailability of wood on-farm, high rate of biomass production, easy to cultivate, and wider adaptability, no palatability to livestock (Mekonnen \& Aticho, 2011).

Some of the environmental and socioeconomic benefits of Eucalyptus species include fuelwood production (for fire), pole production, building, medicinal purposes (e.g. blue gum used to treat flu, the common cold), timber productions (Derba, 2016). In contrast, Eucalyptus has been having undesirable ecological qualities such as depletion of soil water and nutrients, intensive competition with native flora for resources, unsuitability for erosion control, production of an allelopathic chemical that inhibit the growth of other plants and provision of inadequate food and habitat for wildlife (Haileab, 2010).

\section{MATERIAL AND METHODS}

A total of 19 articles were downloaded from the net and were reviewed severally. The abstract and conclusion were drawn with practical experience in addition to this article writing.

\section{NOMENCLATURE}

Table 1.

Botanical Classification of the Plant

\begin{tabular}{|l|l|}
\hline Kingdom & Plantae \\
\hline Clade & Tracheophytes \\
\hline Clade & Eudicots \\
\hline Clade & Rosids \\
\hline Order & Myrtales \\
\hline Family & Myrtaceae \\
\hline Sub family & Myrtoideae \\
\hline Tribe & Eucalypteae \\
\hline Genus & Eucalyptus \\
\hline
\end{tabular}




\section{THE SPREAD OF EUCALYPTUS AND ITS ADAPTATIVE FEATURES}

Eucalypts planting outside its native environment of Australia started in 1904 in Brazil. Today Eucalyptus plantations cover at least 12 million ha throughout the tropical zone, $90 \%$ of which have been established since 1955 (Turnbull, 1999). Concerns were raised around this time about the adverse effects of these plantations on the environment. Eucalyptus planting on farmlands, stream banks and catchment areas was banned because of these adverse effects. Eucalyptus was used in plantations outside its natural distributions area over 200 years ago in Europe. Native to Australia, it reached South Africa, Nigeria and Brazil between the late nineteenth century and early twentieth century. This species is used in reforestation or afforestation program. E.globulus and E. camaldulenesis are the two species that grow anywhere in the world (Getachew, 2016). Since then, the plant was expanded to all corners of the country, and concerns were felt around this time about the adverse effects of the plantation environment. Eucalyptus has increased in importance globally because many species of eucalyptus can improve conditions in treeless areas. Eucalyptus has raised people's livelihood by providing several ends uses, and many farmers continue to plant and use them as building materials, fuelwood and charcoal making. Locally they are also found in shelterbelt, shady groves in and around the village, churches and other dwellings. They also make up a significant source of honey and their leaves as a traditional medicine to fight flu and fever.

The Rapid growth rates in eucalypts have been attributed to indefinite shoots (i.e. a growing tip that produces pairs of leaves at irregular intervals) and do not have resting buds. With these characteristics, eucalypts can grow both in height and length infinitely under favourable conditions. When a branch or shoot is damaged, the "naked bud" or the growing tip, which can further produce a branch of following order, immediately becomes the central bud. As the upper crown increase in height, the lower parts of the trunk are built up, resulting in large volumes of wood per hectares (FAO, 1979). Eucalyptus, a very successful tree, adapts to a variety of habitats with evolutionary adaptive features such as tolerance of severe periodic moisture stress through xeromorphic leaves, stomata close when water potential deficits in the leaf are high, hairy juvenile leaves (some species), volatile leaf oils, deciduous in the dry season (few species), low soil fertility tolerance through the adaptive capacity to soil with low nitrogen and phosphorus content. Specialized nutrients intakes system of eco-and endo-mycorrhizae that increase phosphorus uptake mainly and also zinc, copper, ammonium, tolerance of fire damage through lignotubers (underground organs) thick barks, dormant bud system and tolerance of insect damage by oils and phenolic compounds have been developed by the plant (Haileab, 2010). Eucalyptus usually matures within 5-25 years. Tending of Eucalyptus coppices is done to generate second and subsequent parents of Eucalyptus. Coppices are derived from dormant buds on the cambium of cut trees. Dominant Coppice shoots with a good attachment to the stump should be selected for retention (Kaumi, 1983).

Shoots that are chosen should be as deep down the stump as possible and as wide apart as practicable. Windward shoots are preferred. The root crowns of certain Eucalyptus species are lingo tuberous, which facilitate coppice production. Lignotubers are swellings at the stem base that comprise a mass of tissue that assist the tree to sprout should the main stem die. E.delegatensis and E. regnans species hardly regenerate from coppices (Konuche, 1989). Even though the rural livelihood index of Eucalyptus have been established, E.globulus are 
undermined by several scientists and communities because of the belief that "there are significant negative environmental challenges associated with Eucalyptus trees". Most criticisms draw their strength from a range of technical, ecological, and socio-economic arguments (FAO, 1988).

\section{SOCIO-ECONOMIC AND HEALTH VALUES OF EUCALYPTUS}

In the countries where $85 \%$ of the population depends on subsistence farming, which is usually outdated Agriculture, poverty increase and food insecurity become a significant concern for policymakers and government. Eucalyptus significantly contributes to household livelihood improvement, which reduces poverty significantly. Eucalyptus is the largest nonagricultural source of household income (Jigger \& Pender, 2000). Eucalypts trees have many distinctive characteristics compared to other indigenous trees. Farmers grow eucalyptus trees to fulfill scarcity of fuelwood and construction materials.

Eucalyptus plantation had prevented financial crisis for many poor farmers on land not suited to sustainable agricultural practice. In many developing countries, the area of private planting was much greater than that planted by government departments or industries (Gessesse \& Tekilu, 2011). The plantations have increased job opportunities both in the plantations and processing industries (FAO, 1985). Eucalyptus species are economically important tree species; hence, they are very useful. Eucalyptus is used for fuelwood, charcoal, timber, poles, posts, mine props, poly-wood, paper pulp, fiberboard, tanning, oil, shade \&shelter, ornamental purpose $\&$ as a source of nectar for honey production (Haileab, 2010). The Eucalyptus species is very marketable, which gives it a competitive edge over other tree species and contributes to the growth of the national economy (Jaleta et al., 2016).
Originally native to Australia, eucalyptus trees are now grown worldwide and used for medicinal purposes. Their healing potential is attributed to eucalyptus oil, which is made from the tree's oval-shaped leaves. They are dried, crushed, and distilled to give up the essential oil.

The extracted oil must be diluted before being taken as medicine. Nine benefits of eucalyptus oil are discussed below. Eucalyptus oil has been used to relieve coughing. Currently, most over-thecounter cough medications have eucalyptus oil major active ingredient. Vicks Vapo-Rub, for instance, contains about 1.2 per cent eucalyptus oil and other cough suppressant ingredients. The popular rub is applied to the chest and throat to relieve cough symptoms from the common cold or flu. Inhaling vapour made with the essential oil can loosen mucus so that when you do cough, it's expelled. Using a rub containing eucalyptus oil will produce the same effect. Mosquitoes and other biting insects carry diseases that can be dangerous to our health. Avoiding their bites is our best defence. DEET sprays, a popular repellant, are made with strong chemicals. Alternatively, for those who are not able to use DEET, botanical compounds can repel the pests. The Australian aborigines used eucalyptus leaves to treat wounds and prevent infection. Today the diluted oil may still be used on the skin to fight inflammation and promote healing. You can purchase creams or ointments that contain eucalyptus oil. These products may be used on minor burns or other injuries that can be treated at home. Respiratory conditions such as asthma and sinusitis may be helped by inhaling steam with added eucalyptus oil. The oil reacts with mucous membranes, not only reducing mucus but helping loosen it so that you can cough it up. It's also possible that eucalyptus blocks asthma symptoms. For people who are allergic to eucalyptus, it may worsen their asthma. More research is needed to determine how eucalyptus 
affects people with asthma. Eucalyptus oil has the potential as a treatment for diabetes. Although we know little, experts believe it may play a role in lowering blood sugar in people with diabetes. Researchers have not yet figured out how the essential oil works. However, until more is known, the scientific community recommends careful blood sugar monitoring for people using diabetes medication with eucalyptus oil. The anti-inflammatory properties of eucalyptus can reduce symptoms of herpes. Applying eucalyptus oil to a cold sore can ease pain and speed up the healing process.

\section{SHADING EFFECTS OF EUCALYPTUS ON CROPS}

Due to their rapid growth, exotics trees plantation are usually taller than other plants of same age, and their shade may affect nearby crops by reducing the sunlight needed for growth. Because of shading and competition for water, the yields from crops close to Eucalyptus plantations are most times not as good as they are further away from the edge (Demel, 2000). Therefore, eucalyptus trees often reduce crop yields on plots next to wood lots or rows of trees and the allopathic effects of eucalyptus and competition for nutrients when planted next to food crops or intercross with cereals or vegetables may lead to a loss in food crop production that may affect household food security and income. Allelopathy is the release of chemicals from leaves or litters that inhibit the germination or growth of other plant species and consequently reduce the output of crops (FAO, 1985).

Table 2.

Noted ecological effects of Eucalyptus

\begin{tabular}{|c|c|c|}
\hline Effects & Positive effects & Negative effects \\
\hline $\begin{array}{c}\text { Biomass } \\
\text { production }\end{array}$ & $\begin{array}{c}\text { Short term options for the provision of critically } \\
\text { required biomass is the planting of fast-growing } \\
\text { eucalyptus. }\end{array}$ & The scarcity of Land is a constraint \\
\hline $\begin{array}{c}\text { Effects on soil, } \\
\text { nutrient } \\
\text { depletion and } \\
\text { top soil } \\
\text { retention }\end{array}$ & $\begin{array}{c}\text { On degraded hillsides and wastelands, the net soil } \\
\text { nutrient contribution of Eucalyptus through leaf } \\
\text { litter is likely to be positive. }\end{array}$ & $\begin{array}{c}\text { Eucalyptus trees deplete soil nutrients } \\
\text { Needed by agricultural crops, } \\
\text { however the spatial magnitude of } \\
\text { depletion is not known. }\end{array}$ \\
\cline { 2 - 4 } & $\begin{array}{c}\text { Good potential for topsoil retention on degraded } \\
\text { hillside. }\end{array}$ & $\begin{array}{c}\text { The ability of Eucalyptus to provide } \\
\text { organic matter is questionable. }\end{array}$ \\
\hline $\begin{array}{c}\text { Allelopathic } \\
\text { effects }\end{array}$ & $\begin{array}{c}\text { Rainfall may decrease or negate the allelopathic } \\
\text { effects of trees on crop. }\end{array}$ & $\begin{array}{c}\text { Allelochemicals negatively influence } \\
\text { agricultural production and are a } \\
\text { more significant factor in dry regions. }\end{array}$ \\
\hline $\begin{array}{c}\text { Hydrological } \\
\text { impact }\end{array}$ & $\begin{array}{c}\text { In regions with erratic and severe rainfall the } \\
\text { ability to take up large quantities of water may } \\
\text { reduce runoff, flooding and water logging. }\end{array}$ & $\begin{array}{c}\text { Eucalyptus may complete water away } \\
\text { from agricultural crops decreasing } \\
\text { agricultural output up to 10 meters } \\
\text { away from trees plantation. }\end{array}$ \\
\cline { 2 - 4 } & $\begin{array}{c}\text { On previously barren slopes, tree cover may } \\
\text { reduce erosion and gully formation caused by } \\
\text { rainfall. }\end{array}$ & $\begin{array}{c}\text { Wide-scale hydrological impacts are } \\
\text { uncertain. }\end{array}$ \\
\hline
\end{tabular}

Source: Jigger and Pender, 2000

\section{CONCLUSION}

It is known that natural forests supply a wide variety of benefits that is very important or useful to the local communities in the long term, plantation may still supply more significant quantities of materials within a short time. Advantages of Eucalyptus include industrial wood, poles, timber, fuelwood, bee forage, essential oils, and several environmental services such as windbreaks, erosion control, buffer to natural forests, flood control, and climate 
change mitigation. In addition, eucalyptus is also presently used in construction and woodwork. So, planting Eucalyptus has excellent benefits for society in improving their socio-economic livelihood and

\section{Reference}

Boland, D. J., Brooker, M. I. H., Chippendale, G. M., Hall, N. Hyland, B. P. M. and Johnson, R. D. (2006). Forest trees of Australia. Melbourne, CSIRO, Australia

Demel, T (2000). Facts and experience on eucalyptus in Ethiopia and elsewhere: ground for making wise and informed decision. Workshop on Eucalyptus Dilemma, 15 Nov, 2000

Derba, B. (2016) .Socio economic importance of selected Indigenous and Exotic Tree Species used in Dabat district, North Gonder, Ethiopia.

FAO (1979) .Eucalyptus for planting .FAO forestry and forest product study NO.11.679PP. FAO, Rome.

FAO (1985). The ecological effect of Eucalyptus. FAO. Forestry paper NO.59.FAO. Rome.

FAO. (1988). The Eucalyptus dilemma. No.26 pp. Rome, Italy.

Gessesse, D. Tekilu,E. (2011). Eucalyptus in east Africa, socio-cultural and environmental Issue, planted forest Tree Working paper 46/E Forest Management Team, FAO, Rome.

Getachew, A (2016). The impact of Eucalyptus expansion on food security In Bambasi woreda. Benishngul Gumuz regional state, western Ethiopia.

Gindaba J.2003. Water and nutrient relations of selected tree species of Ethiopia. PhD dissertation. University of Stellenbosch, South Africa. 2003; 190. 63.

Haileab, Z (2010) .Environmental socio economic implications of Eucalyptus in Ethiopia, INGil, L, Wubalem Tadesse, Tolosana, E. and Lopez, R. Processing the conference on Eucalyptus species management, History, status and trends in Ethiopia pp. 184 -205. EIAR. Adiss Ababa. regulating climate change, enhancing healthy living.

Jagger, P. Pender.J, (2000). The role of trees for sustainable management of less favored land the cause of Eucalyptus in Ethiopia, EPTD Discussion paper, No.65.

Jaleta D, Mbilinyi B. Mahoo H, Lemenih M., (2016). Eucalyptus Expansion as Relieving and Provocative Tree in Ethiopia. JAERI, 6(3): 1-12, www.sciencedomain.org.

Kaumi, S.Y.S. (1983). Four rotations of Eucalyptus yield trial. Commonwealth Forestry Review 62: 19 - 24.

Konuche, P. K. A. (1989). Results of Eucalyptus species trial at Londiani.KEFRI Technical Note, No 6.

Mekonnen T, Aticho A (2011). The driving forces of Boye wetland degradation and its bird species composition, Jimma, Southwestern.Journal of Ecology and the Natural Environment. 3:365-369. 58.

Turnbull JW (1999). Eucalypt plantations. New Forests 17, 37-52. 


\title{
FEATURES OF TEACHING HUMANITIES IN HIGHER EDUCATION INSTITUTIONS FOR FUTURE SPECIALISTS IN HOTEL AND RESTAURANT BUSINESS AND TOURISM
}

\author{
Lesia Zelman ${ }^{1}$, Oleksandr Mykytenko ${ }^{2}$
}

Received: 2021-05-04

Accepted: 2021-07-08

DOI: http://doi.org/10.46489/gpj.2021-1-2-4

Abstract. We have considered the features of professional training of specialists in the hotel and restaurant business and tourism. In the analysis of the curriculum, we appear to find a place in the training of future specialists in hotel and restaurant business and tourism in the study of humanities, namely: "Ukrainian language for professional purposes", "World culture and art", "Foreign language for professional orientation", "Fundamentals of professional ethics and culture of communication", and other. During the course, participants of the educational process must make efforts to form a communicative culture, critical thinking and aesthetics of speech. Future masters of hotel and restaurant business and tourism must be at a high level of management of communicative culture and content to think critically. The humanities cycle subjects basing on the text, with the help of which educational activities are carried out, training of future specialists of hotel and restaurant enterprises and tourism takes part in professional texts that help students accumulate professional terminology and form professional skills. We concluded that introducing elements of the dual system of education is a positive trend in the training of hotel and restaurant professionals and tourism. Students can assimilate and improve communication culture, see bottlenecks and make an effort to correct and improve themselves.

Keywords: hotel and restaurant business, tourism, humanitarian subjects, communicative possibilities, professional text.

\footnotetext{
${ }^{1}$ Lesia Zelman, PhD in Pedagogical Science, Head of the Department of Social Sciences and Humanities, Lviv University of Business and Law, Kulparkivska str., 99, Lviv, Ukraine, ORCID: https://orcid.org/0000-0002-2497$7292 X$

2 Oleksandr Mykytenko, PhD student, Senior Lecturer, Department of Social Sciences and Humanities, Lviv University of Business and Law, Kulparkivska str., 99, Lviv, Ukraine, oleksandr.mykytenko.robota@gmail.com ORCID: https://orcid.org/0000-0002-5983-7548
} 


\section{ВСТУП}

Постійні зростанням вимог до професійної діяльності зумовлені динамічними змінами сучасності. Для фахівця сфери «людина-людина» як чинник успішної професійної діяльності $\epsilon$ формування професійної комунікативної культури. Розвиток комунікативних здібностей майбутніх фахівців готельно-ресторанної справи та туризму $€$ важливою складовою їх професійної підготовки, адже від уміння налагоджувати контакт, ефективно спілкуватися залежить продуктивність їх майбутньої професійної діяльності. Комунікативні здібності майбутніх фахівців формуються під час вивчення гуманітарних предметів. Такі навчальні предмети мають максимально працювати над формуванням професійних компетенцій. Питання професійної підготовки зазначених фахівців досліджені в публікаціях багатьох науковців: I. Babii, O. Dolhopol, S. Vdovych, O. Zamferesko, L. I. Matsko, L. M. Palamar, M. I. Pentyliuk, V. Poluda, L. Rudenko, O. M. Semenoh та ін. Незважаючи на значну кількість досліджень із вказаної теми, проблема формування комунікативної культури майбутніх фахівців у навчальних закладах під час вивчення дисциплін саме гуманітарного циклу є актуальною, це і зумовило вибір теми наукового дослідження. Актуальність теми зумовлена також і тим, що в сучасних умовах збільшилася кількість професій типу «людина - людина», які необхідні у багатьох сферах. Аналіз досліджень свідчить, що вивчення гуманітарних дисциплін формує професійні якості майбутніх фахівців готельноресторанної справи та туризму.

Мета статті - з'ясувати особливості викладання гуманітарних дисциплін для майбутніх фахівців готельноресторанної справи та туризму у вищих навчальних закладах.

\section{РЕЗУЛЬТАТИ}

У сучасних соціально-економічних умовах збільшилася кількість професій сфери обслуговування, які здійснюють діяльність у багатьох сферах: готельноресторанна справа, туризм побутове обслуговування, роздрібна торгівля, житлово-комунальне господарство, фінансові послуги, соціальне забезпечення населення, медичне обслуговування та ін. Професійна діяльність майбутнього фахівця - це не лише ставлення фахівця до об'єкта праці, а й стосунки зі співробітниками та клієнтами. У професіях типу «людина - людина» вимоги до працівників значно зростають, від них вимагається не лише висока кваліфікація, але і глибоке усвідомлення свого морального обов'язку перед людьми. Основне завдання майбутнього фахівця - якісне надання послуг, тому, крім професійних аспектів, варто значну увагу приділити формуванню особистісних якостей фахівця а саме: пунктуальності, тактовності, дисциплінованості, працелюбності, ініціативності, комунікативність, чесності, порядності та ін.

Сьогодні випускники закладів, вступаючи в самостійне життя, відчувають на собі труднощі формування чітко визначених життєвих орієнтирів та суттєву розбіжність між змістом життя i змістом того, чого навчалися, тому сучасна парадигма освіти, на думку В. Кудіна (Osvitni paradyhmy suchasnosti, n.d.), повинна спиратися на такі принципові тези:

1. Освіта за своїм змістом і метою єдина для всіх, як єдині відкриття науки. Освіта має бути наукоємкою.

2. Пропоновані системою освіти вимоги, їх об'єднані для всіх країн i народів, вони обумовлюють потребу в створенні загальнопланетарного педагогічного простору, заснованого на необмеженому прагненні до 
досконалості і розширенню меж пізнання.

3. Освіта має спиратися на наукову і культурну основу розвитку особистості, сприяти формуванню людини 3 інноваційним типом мислення, культури i поведінки, здатної розвиватися самостійно в контексті зростаючого об'єму інформації.

4. Творче застосування отриманих знань, втілення їх у практичній діяльності 3 усвідомленням максимальної відповідальності за наслідки своїх дій та вчинків.

5. Освіта має бути джерелом радості і задоволення для тих хто навчає та тих кого навчають.

Підготовка майбутніх фахівців готельно-ресторанної справи та туризму потребує вдосконалення технологій навчання та «приведення завдань професійно-комунікативної підготовки у відповідність до вимог культурологічно, синергетично й особистісно орієнтованої нової освітньої парадигми задля формування комунікативної культури, яка визначає конкурентоспроможність випускників закладів на ринку праці» (Rudenko L. A., 2015).

Таким чином, аналізуючи вищесказане, зазначимо, що сучасні навчальні заклади мають підготувати сьогоднішнього студента до успішної професійної діяльності, заклади освіти покликані не просто дати студентам суму знань, умінь i навичок, a формувати в них компетентність як загальну здатність, що грунтується на знаннях, досвіді, цінностях, здібностях, отриманих завдяки навчанню. Студенти повинні на високому рівні володіти власне професійною діяльністю в обраній галузі; вміти проектувати свій подальший професійний розвиток; володіти навичками морально-правової відповідальності за якість і результати своєї праці.

$\begin{array}{lcr}\quad \text { Професійні } & \text { якості } & \text { фахівця } \\ \text { грунтуються } & \text { на } & \text { знаннях } \\ \text { фундаментальних, } & & \text { професійно }\end{array}$
орієнтованих i гуманітарних наук, уміннях i навичках виконувати професійні обов'язки. Навчальні предмети, які вивчають студенти під час навчання у вищому навчальному закладі, мають максимально працювати над формуванням професійних компетенцій. Важливий вплив на формування особистості студента відіграють гуманітарні предмети, вивчення яких в навчальному закладі допоможе студентам виробити та вдосконалити свої професійні якості, які згодом допоможуть їм реалізувати себе як фахівця. Тому вважаємо, що предмети гуманітарного циклу займають вагому нішу в новітній освітній парадигмі, адже розвивають в студентів передусім комунікативні здібності та творчу уяву. Результатом комунікативної підготовки має стати готовність студента до професійного спілкування - багатопланового складного процесу налагодження i розвитку контактів між людьми у процесі професійної діяльності, в результаті якого здійснюється взаємовплив особистостей, обмін між ними інформацією та вироблення загальної стратегії взаємодії, сприйняття, розуміння. Важливе значення має і естетика мовлення, яку студенти черпають під час читання творів, різноманітних текстів, а на заняттях вчаться правильно аналізувати прочитане та висловлювати свою думку. Естетика мовлення тісно пов'язана 3 естетикою діяльності особистості фахівця, який повинен прагнути бачити красу в кожній людині, у будь-якій діяльності та в навколишньому середовищі. Від безпосередності та щирості такого прагнення буде залежати ефективність його спілкування, а отже, і професійної діяльності (Vdovych, S. М., 2012). Ці ознаки свідчать про культуру мовлення 
особистості,

яку

на

студенти

вдосконалюють

заняттях

гуманітарних дисциплін. Вивчення предметів гуманітарного циклу у вищих навчальних закладах дозволяє розвивати не тільки комунікативні здібності, а у готує студентів готельноресторанної справи та туризму до самостійної творчої діяльності. Велике значення має розвиток творчості, адже саме люди 3 творчим мисленням приносять у життя щось нове. Такі люди найчастіше стають лідерами. Творчість має вирішальне значення в розвитку здібностей людини, формуванні їі активної життєвої позиції.

Зазначимо, що 13 січня 2010 р. № 85-р схвалено розпорядженням Кабінет Міністрів України Концепцію проекту Закону України «Про основні засади державної комунікативної політики», де зазначається, що виховання нового покоління має спрямовуватись на формування в людей комунікативної культури (Kontseptsiia proektu Zakonu Ukrainy «Pro Osnovni zasady derzhavnoi komunikatyvnoi polityky»).

На сьогодні уже сформована нормативно-правова база, відповідно до якої здійснюється професійна підготовка фахівців готельноресторанної справи та туризму. При аналізі навчальних програм 3'ясовано, що важливе місце у підготовці майбутніх фахівців готельноресторанної справи та туризму належить вивченню предметів гуманітарного циклу. Проаналізуємо дещо детальніше особливості вивчення предметів гуманітарного циклу $\mathrm{y}$ вищому навчальному закладі. Це доцільно здійснювати під час суспільногуманітарної підготовки при вивченні предметів «Українська мова за професійним спрямуванням», «Світова культура та мистецтво», «Іноземна мова за професійним спрямуванням», «Основи професійної етики та культури спілкування» та ін. Вивчення предметів гуманітарного циклу в навчальному закладі допоможе студентам виробити та вдосконалити свої комунікативні здібності, які згодом допоможуть їм реалізувати себе як фахівця, адже спілкування має важливе значення для досягнення успіху в професійній діяльності.

В основі предметів гуманітарного циклу лежить текст (художні, науковий), за допомогою якого відбуваються навчальні дії. При вивченні предметів гуманітарного циклу навчальний текст виконує низку дидактичних функцій:

1) пізнавальну: а) предмет спостереження й осмислення виучуваного лексико-граматичного матеріалу; б) джерело нової мовної інформації; в) матеріал для створення проблемних завдань;

2) навчальну: а) формує й розвиває комунікативні навички; б) слугує зразком мовленнєвої культури, правильності усного й писемного мовлення; в) демонструє стилістичну варіативність мовлення та функціонування різнорівневих мовних одиниць у межах певного функційного стилю;

3) розвивальну: а) розвиває мовні/мовленнєві здібності учнів; б) розвиває комунікативну компетенцію; в) розвиває мовленнєву ініціативу;

4) комунікативну: а) спонукає учнів до мовленнєвого спілкування; б) $\epsilon$ джерелом навчального діалогу/полілогу між учителем i учнями; в) $\epsilon$ зразком моделювання ситуацій спілкування (Babii I. V., 2015).

Як бачимо, комунікативні здібності майбутніх фахівців формуються під час вивчення гуманітарних предметів, тому основне завдання гуманітарних дисциплін забезпечити розвиток та формування професійної комунікації. При виборі тексту на заняття для підготовки майбутніх фахівців готельно-ресторанної справи та туризму важливо здійснювати на основі 
фахових текстів. «Робота із правильно дібраними й системно організованими текстами дозволяє формувати окремі мовні поняття, демонструвати взаємодію всіх мовних засобів (фонетичних, лексичних, граматичних), забезпечує формування комунікативних умінь і навичок, а також $\epsilon$ одним із засобів управління мотивацією учнів під час організації мовленнєвої діяльності» (Babii I. V., 2015). Є. Кулькіна зазначає, що фахові тексти за спеціальністю вважаються не лише основним джерелом для накопичення фахової термінології, але й засобом становлення й розвитку професійної майстерності та професійно орієнтованої ерудиції (Kulkina Ye. A., 2007).

На заняттях при аналізі текстів студенти вчаться мислити, ставити продумані запитання, зіставляти факти й аналізувати свої думки. Студенти уважно мають слухати опонента, щоб оцінити його висловлювання та сформулювати логічні запитання - усе це створює можливості для формування навичок критичного мислення, які пов'язані 3 умінням добувати, опрацьовувати та використовувати інформацію 3 різних джерел, а також викладати результати її аналізу в стислій формі. Таким чином, студенти охоплені активною творчою навчальною діяльністю на заняттях, залучені до процесу самонавчання, самореалізації, вчаться спілкуватися, співпрацювати, критично мислити, обстоювати свою позицію. Формування навичок критичного мислення конкурентноздатність і мобільність освіченої людини на ринку праці, її готовність жити і працювати в умовах неперервних змін. Критичне мислення це процес, який найчастіше починається з постановки проблеми, продовжується пошуком і осмисленням інформації. Закінчується такий процес прийняттям рішенням щодо розв'язання поставленої проблеми (Vykorystannia tekhnolohii krytychnoho myslennia yak zasobu stvorennia tvorchoho mikroklimatu na urotsi svitovoi literatury, n.d).

Babii I. V. (2015) виділяє такі критерії відбору навчального текстового матеріалу, що сприятимуть формуванню відповідних компетенцій у майбутніх фахівців сфери обслуговування:

1. Інформаційний. Текст знайомить учнів із новою інформацією, що стимулює їхню інтелектуальнопізнавальну діяльність.

2. Методичний. Відібраний текстовий матеріал повинен бути придатним для створення на його основі системи мовних, мовленнєвих і комунікативних вправ i завдань. Зазначено, що саме цей критерій повинен бути основним у відборі текстів для навчальних потреб.

3. Лінгвістичний. Тексти повинні давати студентам повне уявлення про функційні стилі сучасної української мови, бути насиченими комунікативно значущою лексикою, граматичними конструкціями, що розширюватиме словниковий запас, ілюструватиме відповідні мовні явища.

4. Комунікативний. Комунікативні вміння й навички формуються засобами навчального тексту та системи післятекстових вправ і завдань.

5. Виховний. Текстовий матеріал $\epsilon$ основним засобом реалізації виховних можливостей предмета «Українська мова», що дозволяє залучити учасників до духовної культури українського народу, розширити їх світоглядні обрії, сприяє формуванню свідомої мовної особистості, що можливо за умов використання найрізноманітніших за змістом і стилем текстів.

6. Критерій доступності відповідає одному із загальнодидактичних принципів й передбачає, що текстовий навчальний матеріал повинен бути доступним учням, а саме враховувати їх вікові особливості, рівень мовної 
підготовки, когнітивного розвитку [2, c. 88].

\section{ВИСНОВКИ}

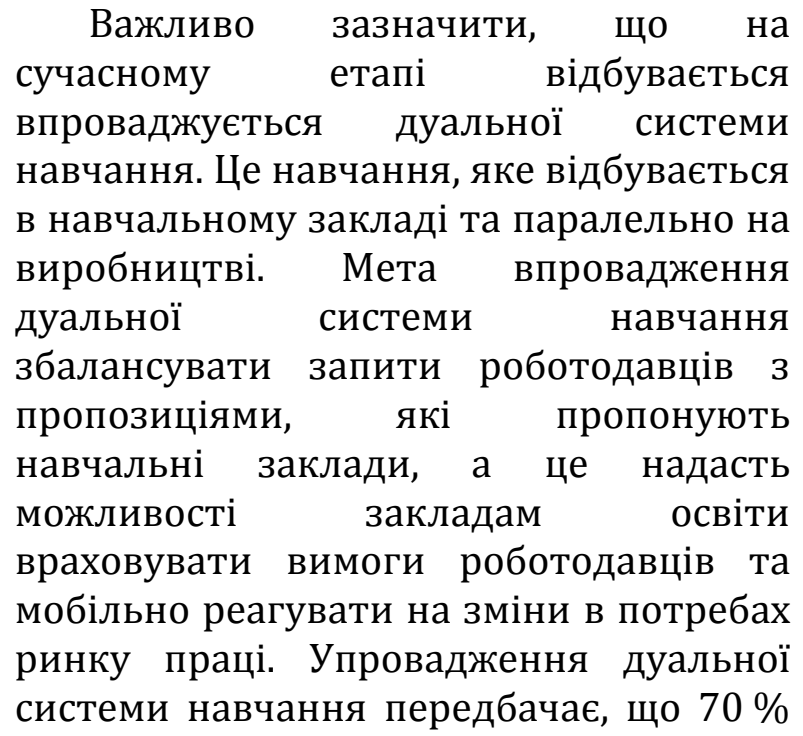

\section{References}

Babii I. V. (2015). Pedahohichni umovy rozvytku profesiinoho movlennia uchniv profesiino-tekhnichnykh navchalnykh zakladiv sfery obsluhovuvannia: dys. kand. ped. nauk: 13.00.04. $245 \mathrm{~s}$.

Kontseptsiia proektu Zakonu Ukrainy «Pro Osnovni zasady derzhavnoi komunikatyvnoi polityky». Retrieved from http://zakon2.rada.gov.ua/laws/show/852010-\%D1\%80.

Kulkina Ye. A. (2007). Pryiomy roboty z navchalnymy tekstamy z anhliiskoi movy na peredtekstovomu etapi. Inozemni movy v shkoli. No 5. P. 44.

Osvitni paradyhmy suchasnosti (n.d.). Retrieved from https://studopedia.su/16_148949_osvitniparadigmi-suchasnosti.html

Rudenko L. A. (2015). Formuvannia komunikatyvnoi kultury maibutnikh fakhivtsiv sfery obsluhovuvannia $u$ profesiino-tekhnichnykh navchalnykh zakladakh: monohrafiia. Lviv: Piramida. $343 \mathrm{~s}$.

Vdovych, S. M. (2012). Shliakhy vdoskonalennia movnoi pidhotovky uchniv PTNZ iz vykorystanniam suchasnykh osvitnikh tekhnolohii. Humanitarna osvita i potreby rynku pratsi: monohrafiia, za red. практичної підготовки майбутнього фахівця проходитиме безпосередньо на виробництва, а на теоретичні заняття планується до 30\%. Такі умови дозволять студенту оцінити рівень комунікативної культури та мати можливість їі виправити та вдосконалити.

Таким чином, сучасна освіта має підготувати фахівця готельноресторанної справи та туризму, який зуміє реалізувати свої професійні здібності в сучасному суспільстві, тому предмети гуманітарного циклу беруть активну участь у формування такої особистості, а отже, займають важливе місце в освітній парадигмі.

H. P. Vasianovycha, S. M. Vdovych. Kyiv : Pedahohichna dumka. S. 85-106.

Vykorystannia tekhnolohii krytychnoho myslennia yak zasobu stvorennia tvorchoho mikroklimatu na urotsi svitovoi literatury. (n.d). Retrieved from http://oin.in.ua/vykorystannyatehnolohiji-krytychnoho-myslennya-yakzasobu-stvorennya-tvorchohomikroklimatu-na-urotsi-svitovojiliteratury/

Zelman L. N. (2017). Pidhotovka kvalifikovanykh robitnykiv sfery obsluhovuvannia u profesiinotekhnichnykh navchalnykh zakladakh Ukrainy (1969 r. - pochatok KhKhI stolittia): dys. kand. ped. nauk: 13.00.04 / Zelman Lesia Nestorivna; Lvivskyi derzhavnyi universytet bezpeky zhyttiediialnosti. L.,. 276 s. 


\title{
CONTRACTUAL DELEGATION OF SOVEREIGNTY IN SUPRANATIONAL ENTITIES
}

\author{
Zhanna Zavalna ${ }^{\mathbf{1}}$, Mykola Starynskyi
}

Received: 2021-06-03

Accepted: 2021-07-14

DOI: http://doi.org/10.46489/gpj.2021-1-2-5

\begin{abstract}
The article analyses the agreement basis for state sovereignty as established and implemented in the European Union. The research aims to study the agreement-based regulation used by the EU Member States to create a stable position of Ukraine on its way to becoming a member of the European Union. The research allowed finding out that the member states do not transfer their powers in their economic and social fields but only delegate them. The analysis of the treaties concerning the establishment and functioning of the European Union proves the existence of specific organisational and legal intervention measures that the countries agree to when joining the treaty union. The agreement-based rearrangement of powers between the EU and its member states lets the latter obtain their special legal personalities regarding the conclusion of agreements among themselves and at the same time preserve complete economic sovereignty in their relations with the countries that are not member states of the EU. When joining the European Union, its member states voluntarily and on a negotiable basis agree to certain restrictions and prohibitions binding in their economy. Furthermore, the EC Treaty provides for the improved protection of interests for the economic community as compared with the protection of national interests of the member states though it is not excluded that the latter can be taken into consideration when adopting the national laws of a member state to the EU legislation.
\end{abstract}

Keywords: treaty, treaty union, European Union, powers, cooperation, community, sovereignty.

\footnotetext{
1 Zhanna Zavalna, Doctor of Law, Professor, Professor of the Department of Civil Law, V.N. Karazin Kharkov National University, Kharkyv, Svobody sq., 4, 61 022, Ukraine, e-mail: zavaln@karazin.ua, ORCID: https://orcid.org/0000-0001-6511-2482

2 Mykola Starynskyi, Doctor of Law, Professor, Professor of the Department of Administrative, Economic Law and Financial and Economic Security, Academic and Research Institute of Law, Sumy State University, Sumy, Rimskogo-Khorsakova str., 2, 40000, Ukraine, e-mail: starinskiy_nik@ukr.net, ORCID: https://orcid.org/00000003-2661-5639
} 


\section{ВСТУП}

Європейський вибір прийнято вважати невід'ємною складовою національної ідеї і одночасно стратегічним напрямом державноправового розвитку України, внаслідок чого курс на європейську інтеграцію $\epsilon$ найважливішим зовнішньополітичним пріоритетом України. Кожна держава, яка взяла напрямок на інтеграцію у європейський економічний простір, постала перед завданням обрання одного $з$ двох напрямків розвитку конкуренції чи співробітництва. На сьогоднішній день, для врівноважування цих двох антагоністичних сил держави укладають різного роду договори, в тому числі про створення наддержавних співтовариств. Одним із таких державних об'єднань $\epsilon$ Європейське співтовариство. Європейський Союз виставив доволі жорсткі умови для набуття членства. Це можна пояснити тим, що Європейський Союз хоче бачити серед своїх членів тільки ті держави, які належать до європейського цивілізаційного пласту, і сприймають та впроваджують у своє політичне i економічне життя цінності об'єднання, а не будь-яку державу, яка географічно належить до Європи. Умови вступу до Європейського Союзу були ускладнені на етапі прийняття в союз країн Центральної і Східної Європи (Falalieieva L. H., 2017.).

Існування та розширення меж Європейської спільноти відбулось на основі цілої низки договірних актів (Маастрихтський договір, Ніццький договір - далі Договір про ЄС, ДЕС), які втілюють доволі цікаві як для теорії, соціології, економіки права умови входження та перебування держав в такому співтоваристві. Аналіз та дослідження основоположних статутних документів $є$ необхідним для вивчення досвіду функціонування держав-учасниць в договірних наднаціональних союзах 3 метою формування сталої позиції на шляху входження України до Європейського Союзу.

Здатність Європейського Союзу сприяти ефективному вирішенню завдань та реалізації економічних функцій держав $\epsilon$ одним із головних факторів, що обумовлюють доцільність його існування як для держав-учасниць, так i для країн-сусідів та державкандидатів, а також виправдовує практику делегування державамиучасницями наднаціональному утворенню своїх суверенних прав та повноважень. Для кращого розуміння проблем державно-правового розвитку в умовах інтегрування держав в європейський простір, необхідно постійно проводити всебічний аналіз теорії i практики реалізації своїх функцій державами в умовах їх членства в договірному міждержавному об'єднанні. Дослідження проблем європейської інтеграції здійснювали науковці, які в своїх дослідженнях вивчали питання загальних засад створення та функціонування економічного та валютного союзу (Butorina, O., 2001, Butorina, 0., 2005), проблеми реалізації державами свого фінансового та економічного суверенітету в глобалізаційних умовах (Petryshyn, O. V, 2010), проблеми реалізації внутрішніх функцій держави в умовах членства в Європейському союзі (Salo, V. I., 2001.); правові питання інтеграції України в ЄC (Siur, N. V., 2006); правових основ інтеграції в $€ C$ (Yakoviuk, I.V., 2004; Yakoviuk, I.V. 2010; Yakoviuk, I.V., 2013). Іноземні автори, приділяли увагу суверенітет в договірних об'єднаннях держав, обговорювали проблеми подільності (Bruno de Witte, 1995) та делегування суверенітету (David A. Lake, 2006), а також позицію Конституційного Суду ФРН в рішенні про державний суверенітет (Roland Bieber, 2009). 
На фоні розмаїття наукових досліджень глобалізаційних процесів залишаються недостатньо висвітленими питання договірного регулювання встановлення та реалізації суверенітету державами-учасницями, які перебувають в міждержавних союзах, зокрема в Європейському Союзі.

\section{РЕЗУЛЬТАТИ}

На сьогоднішній день, в міжнародному праві діє базова теорія європейської інтеграції, яка утверджує позицію співробітництва держав на основі об'єднання суверенітетів. Це означає, що суверенітети держав замінюють i не конкурують один 3 одним, але примножують сили i можливості кожного 3 учасників міждержавного об’єднання. Розгорнуте закріплення змісту принципу наділення компетенцією, що міститься в Лісабонській редакції Договору про ЄС містить дає підстави говорити про те, що держави-учасниці остаточно не передають інститутам $€ C$ свої повноваження у певних сферах. Крім того, введення в нормативне регулювання положення про можливість реалізації свого права на вихід зі складу Європейського Союзу ще раз підтверджує думку про те, що держави-учасниці

залишають суверенними протягом всього часу перебування у міждержавному об'єднанні. Тому мова скоріше йдеться про встановлення певної компетенції для $€ \mathrm{C}$, а також про реалізацію тих повноважень, які держави-члени визнали за доцільне делегувати на наднаціональний рівень за для ефективного здійснення своїх економічних функцій.

Щоб залишатись повноправним суб'єктом міжнародного права, держава має бути суверенною i залишатись такою при входженні в будь-які міждержавні об'єднання. Для цього необхідно, щоб функції і компетенції залишались за державою в повному обсязі, оскільки суверенні права $\epsilon$ невід'ємними правами держави, тому, що базуються на національних нормативних актах. Така позиція відстоюється державами-членами Європейського Союзу, які в договірному порядку передали інститутам Європейського Союзу не самі суверенні права, а тільки можливість їх реалізації чи точніше - підконтрольне їх здійснення.

Рішенням Конституційного Суду ФРН, яке стосувалося питання збереження/передання державного суверенітету у міждержавних союзах, було встановлено, що положення Конституції не уповноважує уряд на передачу суверенних прав держави, а тільки такий спосіб побудови правопорядку, за якого допускається застосування права з іншого джерела в рамках внутрішньодержавної компетенції (Oona A. Hathaway, 2008). Аналіз даного положення показує, що Конституційний Суд відстоює позицію делегування здійснення суверенних прав, що показує факт залишення прав за собою і не йдеться про остаточне відчуження суверенних прав чи окремих повноважень. В даному випадку також йдеться про можливість спільної, разом 3 інститутами $€ C$, реалізації частини внутрішніх повноважень держави до того часу, доки держава виявляє волю бути членом договірного об'єднання (Klemin, A. V. 1996).

Аналіз установчих документів ЄС, а також інших політичних та правових актів, які оформлюють започаткування та здійснення інтеграційного процесу, показує, що держави добровільно делегують свої повноваження, по суті здійснюючи самообмеження щодо реалізації окремих суверенних прав в рамках свого внутрішнього i зовнішнього суверенітету. В даному випадку йдеться не про остаточне вилучення певних повноважень із предмета компетенції держави, а про зміну суб’єкта, що її здійснює. Держави, 
які при плануванні свого подальшого економічного розвитку віддали перевагу концепції співробітництва, добровільно погоджуються на обмеження самостійної реалізації окремих суверенних прав, оскільки очікують від інших держав-учасниць договірного союзу, таких самих кроків. При цьому не інституції Європейського Союзу встановлюють обсяг прав, що передаються, а самі держави-члени. Останні, визначаючи обсяг компетенції, який вони передають інституціям $€ \mathrm{C}$, а також встановлюють рамки для здійснення заходів і рішень Європейською радою і Радою ЄС як інститутів міжурядової співпраці. Дані інституції здійснюють передані повноваження на наднаціональному рівні відповідно до мандату, яким наділила їх кожна із держав учасниць (Yakoviuk, I.V. 2013).

Пропонуємо звернутись до тексту Договору про ЄC i проілюструвати конкретні способи та методи делегування конкретних повноважень держав-учасниць. В Договорі про ЄС передбачається делегування органам $€ \mathrm{C}$ повноважень різних сфер життєдіяльності держави. Пропонуємо розпочати аналіз із повноважень в сфері правотворення та правозастосування. В Договорі про ЄС чітко прослідковується, що держави-учасниці добровільно погоджуються на скасування національних нормативних актів повністю та в частині, якщо вони встановлюють адміністративні процедури та звичаї, а також права, що випливають 3 національного законодавства чи угод між державамичленами, укладених раніше, та що перешкоджають лібералізації вільного пересування працівників, свободі підприємницької діяльності, руху капіталу, розміщення інвестицій тощо. Також, органам $€ C$ встановлюються повноваження на тлумачення окремих статей при їх застосуванні. Так, Комісія $€ C$ може надавати державам-членам рекомендації щодо застосування окремих статей (ч. 3 ст. 77 Договору про $\epsilon C)$.

В договорі про ЄС встановлюються правила ведення переговорів та укладення угод в середині Спільноти, тобто в договірному порядку відбувається переформотування повноважень на встановлення договірного регулювання відносно держав-учасниць. Більш того, спеціально наголошується на обов'язковій силі таких угод для всіх інституцій Спільноти та державучасниць (ч. 3 ст. 111 Договору про ЄС; ч. 3 ст. 133 Договору про ЄC). В даному випадку можна говорити встановлення в договірному порядку спеціальної правосуб'єктності держав-учасниць Спільноти відносно одна одної чи про спеціальний режим найбільшого сприяння, який виражається у застереженнях на кшталт «... без порушення компетенції та угод Спільноти...», «... не порушуючи інтересів Спільноти...», «із врахуванням інтересів Спільноти та державучасниць...» тощо.

Крім того, держави-учасниці делегують керівним органам Спільноти повноваження укладати угоди із державами-не-учасницями у сфері торгівлі послугами та торгівельних аспектів інтелектуальної власності. Але Органи договірного об'єднання не можуть укладати угоди, якщо вони містять положення, що виходять за межі внутрішніх повноважень Спільноти, зокрема коли укладення таких угод можуть призвести до необхідності гармонізації законів чи підзаконних актів держав-членів у сферах, де така гармонізація не передбачена. (ч. 6 ст. 133 Договору про $€ C)$. Це означає, що у держав-учасниць щодо укладення угод із іншими державами, третіми країнами та міжнародними організаціями зберігається повний економічний 
суверенітет (ч. 5 ст. 111; абз. 4 ч. 5 ст. 133 Договору про ЄС).

В результаті аналізу тексту різних редакцій договорів про $Є C$ можна виділити наявність організаційних та правових заходів регуляції відносин в середині співтовариства. При чому, основним завданням організаційних заходів регулювання відносин $\epsilon$ координування зближення держав та сприяння їх економічному співробітництву. Координація зближення держав відбувається в процесі проведення консультаційних заходів та заходів контролю, нагляду та моніторингу. Консультаційні заходи можуть мати позитивний результат, коли сторони дійшли згоди із конкретних питань, коли державиучасниці втілюють обумовлений в ході консультації результат у національне законодавство та економіку. I навпаки, консультації можуть не дати позитивного результату. В даному випадку Рада ЄC на пропозицію відповідного комітету, із яким проводились консультації, видає відповідні директиви або вживає інших доцільних заходів обумовлених в Договорі про ЄС (ст. 96).

Можливість держав-учасниць погоджуватись чи не погоджуватись із результатами консультацій підтверджує те, що держави-учасниці не передають власні суверенні права остаточно, але зберігають їх для можливості приймати рішення на власну користь. Звідси випливає, що Європейський Союз не набуває статусу суверена, який передбачає поєднання здатності від свого імені, самостійно і своїми силами здійснювати владні функції (Cymburskij, V. L. 1993). Крім того, відповідно до ч. 2 ст. 136 Договору про ЄС «...Спільнота та держави-члени виконують заходи 3 урахуванням відмінності національних звичаїв, зокрема у сфері договірних відносин, та потреби підтримувати конкурентоспроможність

економіки Спільноти...» (ч. 2 ст. 136).

Заходи контролю, та моніторингу націлені на забезпечення тісної координації економічних політик держав-членів з метою їх погодження із загальними настановами договірного співтовариства (ст. 99 ДЄС). Для відслідковування результативності зусиль держав-учасниць в договорі передбачається можливість застосування процедур різнобічного нагляду, які дають можливість відслідковувати рух держав-членів до економічного та валютного союзів, а також відслідковувати здійснення заходів направлених на гармонізацію національних законодавств. В результаті моніторингу, контролю та нагляду за діями держав-учасниць Співтовариство оцінює рівень виконання умов, що виставляються до виконання для знаходження в економічному союзі і залежно від рішення державу - держава-учасниця може бути обмежена в правосуб'єктності звільнена від певних прав та обов'язків (абз. 2 ч. 3 ст. 122 ДЄС) чи позбавлена права голосу (ч. 5 ст. 122 ДЄС). Дані заходи $\epsilon$ показником підпорядкованості держав-учасниць загальним правилам в договірному об'єднанні.

В результаті аналізу тексту Договору про ЄС можна констатувати використання таких правових способів регулювання як обмеження $\mathrm{ma}$ заборони. Практика законодавчих обмежень в міждержавних союзах застосовується в тих межах і до тих питань, які дозволяють їх конституційні засади держав-учасниць. (SHevchuk S. V. (2000). В Договорі про ЄС правові обмеження встановлені у вигляді негативних та позитивних приписів 3 приводу належної чи неналежної поведінки держав-учасниць, що виражаються здебільшого у словосполученнях «...не належить виходити за межі...», «...належить 
утримуватися від будь-яких кроків...», «...належить пристосувати...». Залежно від стану координації умов економічного співробітництва в договорі передбачається поступове скасовування встановлених обмежень (ч. 3 ст. 47 Договору про ЄС).

На ряду із доволі м'якими приписами, із якими погоджуються держави-учасниці, Договір про $Є \mathrm{C}$ встановлює велику кількість прямих імперативних заборон, які закріплюються як в окремих розділах документів, так і в статтях по всьому документу. Заборони стосуються кількісних обмежень експорту, імпорту, здійснення платежів, створення представництв, філій чи дочірніх підприємств, будь-яких зловживань домінуючим становищем та інших питань. Закріплюється право самих держав-учасниць встановлювати умови, випадки та міри заборони в економічній сфері. Але в особливо важливих випадках, наприклад щодо розробки та застосування конкретних випадків заборони щодо «...надання кредиту на покриття дефіциту чи будь-які інші кредити ЄЦБ чи центральних банків держав-членів...» керівні органи Спільноти (Рада ЄC) можуть встановлювати такі конкретні випадки заборони виходячи із власного розсуду (ч. 2 ст. 103 Договору про ЄC).

Договір визначає охоронні правові заходи направлені захист прав та інтересів міждержавного об'єднання. Зокрема, встановлюється застереження щодо застосування державамиучасницями заходів та процедур, які б порушували права кожної державичлена чи були б засобом свавільної дискримінації, що направлений проти спільної співпраці. (ч. 1, 3 ст. 58 Договору про ЄC). Окремо передбачені охоронні заходи направлені на захист прав та інтересів держав-учасниць, вжиття всіх потрібних заходів, наприклад, щодо запобіганню порушенню національних законів та підзаконних актів. Умови та строки застосування, потрібність та виправданість організаційних заходів, заходів охорони та захисту встановлюється Радою ЄС на власний розсуд. Але держава-член через серйозні політичні причини та через терміновість, може вжити однобічних заходів захисту, а Комісію та інших держав-членів може поінформувати про такі заходи постфактум.

За одночасної передачі повноважень Спільноті, щодо встановлення настанов, приписів, обмежень, заборон державамучасницям 3 приводу поведінки в договірному об'єднанні, а також вжиття в більшості випадків зазначених вище організаційних та правових заходів координації співпраці на свій розсуд, «...Спільнота не несе відповідальності й не перебирає зобов'язань центральних урядів, регіональних, місцевих чи інших державних органів...».

Таким чином, із наведених вище прикладів положень Договору про ЄС, держави-учасниці 3 одного боку держави добровільно погоджуються дотримуватись обмежень, заборон встановлених договірними документами $€ \mathrm{C}$, а з іншого проявляючи свій державний суверенітет в певних випадках і за певних умов застосовувати односторонні заходи захисту своїх прав та інтересів.

\section{ВИСНОВКИ}

За результатами проведеного дослідження, ми можемо стверджувати, що:

Договір про ЄС слугує основою для делегування державами-учасницями частини своїх повноважень наддержавним інституціям. Такий спосіб перерозподілу повноважень цілком відповідає конституційним принципам сталого співробітництва, субсидіарності і пропорційності, які $\epsilon$ характерними для відносин у міждержавних союзах. 
Всі застосовані в договірних актах про ЄС способи регулювання відносин можна поділити залежно від характеру заходів впливу на держав-учасниць на організаційні та правові. Організаційні заходи включають в себе заходи консультативного характеру та заходи моніторингу, контролю та нагляду. Консультативні заходи державучасниць із відповідними Комітетами Європейського Союзу спрямовані на координацію їх економічних політик із інтересами Європейського Союзу. За допомогою заходів моніторингу, контролю та нагляду відслідковується і оцінюється рівень ефективності тих заходів, які були здійснені державамиучасницями в ході економічного співробітництва. За результатами оцінки діяльності держав-учасниць обсяг їх правосуб'єктності в договірному об'єднанні може змінюватись.

Основними способами закріплення делегованих повноважень $\epsilon$ такі правові способи регулювання як заборони та

\section{References}

Falalieieva L. H. (2017). The role of the Copenhagen criteria in implementation of the European Union values. The Scienti ic Papers of the Legislation Institute of the Verkhovna Rada of Ukraine. 1. P. 114-122.

Dohovir (2005). Dohovir pro zasnuvannia Yevropeiskoi Spilnoty. Konsolidovana versiia stanom na 1 sichnia 2005

roku. https://zakon.rada.gov.ua/laws/sho w/994 017\#Text

Dohovir (2010). Nitstskyi dohovir pro vnesennia zmin ta dopovnen do Dohovoru pro Yevropeiskyi Soiuz, Dohovoriv pro zasnuvannia Yevropeiskykh Spivtovarystv ta deiakykh poviazanykh $\mathrm{z}$ nymy aktiv (2001/C80/01). Konsolidovana versiia Dohovoru pro Yevropeiskyi Soiuz ta Dohovoru pro funktsionuvannia Yevropeiskoho Soiuzu $\mathrm{z}$ protokolamy ta обмеження. Обмеження $\epsilon$ правовими способами регулювання відносин i направлені на встановлення меж, які вказують на обсяги необхідної конкретизації змісту рішень держав, які можна i необхідно приймати в ході економічного співробітництва. Заборони $\epsilon$ правовими способами регулювання відносин в міждержавному союзі і направлені на охорону та захист економічних інтересів співтовариства і сталого функціонування його інституцій.

Фактично існує протистояння національних інтересів державучасниць $\epsilon$. Договір про $\epsilon C$ юридичними засобами закріплює концепцію економічного співробітництва європейських країн, а це означає, що в договорі встановлено порядок (регламент) не скільки урівноважування інтересів держав, скільки розподілу і перерозподілу ризиків, що з'являються в наслідок входження країни в договірне об’єднання.

deklaratsiiamy stanom na 30 bereznia 2010

roku. https://zakon.rada.gov.ua/laws/sho w/994 261\#Text

Butorina, 0. (2001). Ekonomicheskij i valyutnyj soyuz ES (mezhdunarodnyj aspekt). [Doktorskaya disertaciya, MGIMO] Elektronnaya biblioteka dissertacij. Otkryt': http://www.dslib.net/economikamira/jekonomicheskij-i-valjutnyj-sojuzes.html

Butorina, 0. (2005) Ponyatie regional'noj integracii : novye podhody. Kosmopolis. 3 (13). S. 136-145.

Petryshyn, O. V. (2010) Problemy realizatsii derzhavnoho suverenitetu $\mathrm{V}$ ekonomichnii ta finansovii sferakh $\mathrm{v}$ umovakh hlobalizatsii. V Yu. P. Bytiak \& I. V. Yakoviuk (red.). Derzhavnyi suverenitet: teoretyko-pravovi problemy. (Stor. 243268.) Kharkiv: Pravo. 
Salo, V. I. (2007). Vnutrishni funktsii derzhavy $\mathrm{v}$ umovakh chlenstva $\mathrm{v}$ Yevropeiskomu Soiuzi [Kandydatska dysertatsiia, Naukovo-doslidnyi instytut derzhavnoho budivnytstva ta mistsevoho samovriaduvannia Akademii pravovykh nauk

Ukrainy] https://dspace.nlu.edu.ua/bitstream/ 123456789/7859/1/Salo_2007_dis.pdf

Siur, N. V. (2006). Pravova intehratsiia Ukrainy do Yevropeiskoho Soiuzu: teoretyko-pravove doslidzhennia [Kandydatska dysertatsiia, Kyivskyi natsionalnyi unversytet vnutrishnikh sprav] Elektronna biblioteka dysertatsii. http://www.disslib.org/pravovaintehratsia-ukrayiny-do-yevropejskohosojuzu-teoretyko-pravove-doslidzhennja.html

Yakoviuk, I.V. (2004). Derzhavnyi suverenitet natsionalnykh derzhav u skladi Yevropeiskoho Soiuzu: problemy vyznachennia. Visnyk Akademii pravovykh nauk Ukrainy. 3. S. 114-126

Yakoviuk, I.V. (2010). Osoblyvosti vplyvu nadnatsionalnoi orhanizatsii na derzhavnyi suverenitet krain-kandydativ ta krain-susidiv (na prykladi Yevropeiskoho Soiuzu). Visnyk Akademii pravovykh nauk Ukrainy. 3. C. 19-31.

Yakoviuk, I.V. (2013). Pravovi osnovy intehratsii do YeS: zahalnoteoretychnyi analiz. Kharkiv: Pravo. 760 s.

Bruno de Witte (1995) Sovereignty and European Integration: The Weight of Legal Tradition. Maastricht Journal of European and Comparative Law. Vol. 2 iss.
2.

P. $145-$

173. https://doi.org/10.1177/1023263X9 $\underline{500200204}$

David A., Lake. (2006).Delegating Divisible Sovereignty: Some Conceptual Issues. Prepared for the Workshop on "Delegating Sovereignty: Constitutional and Political Perspectives". Duke University Law School. March 34. https://web.law.duke.edu/publiclaw/pdf/wo rkshop06sp/lake.pdf

Bieber, R. (2009) An Association of Sovereign States. European Constitutional Law Review. Vol. 5.Iss. 3. pp. 391 - 406. DOI: https://doi.org/10.1017/S157401960 $\underline{9003915}$

Oona A., Hathaway. (2008) International Delegation and State Sovereignty. Law and Contemporary Problems. Vol. 71. (1). pp. 115-149.

Klemin, A. V. (1996) Evropejskij soyuz i gosudarstva-uchastniki: vzaimodejstvie pravovyh poryadkov (praktika FRG). Kazan'.

Cymburskij, V. L. (1993). Ideya suvereniteta $\mathrm{v}$ posttotalitarnom kontekste. Polis. 1. S. 19-20.

SHevchuk S. V. (2000) Znachennya zagal'nopravovogo principu proporcijnosti dlya viznachennya konstitucijnosti zakonodavchih obmezhen' shchodo realizaciï konstitucijnih prav i svobod (zarubizhnij dosvid). Visnik Akademiï pravovih nauk Ukraïni. 1. S. 69-76. 
Global Prosperity is an academic peer-reviewed open-access e-journal.

The Mission. GPrJ ournal exists to enable scientists worldwide to present the results of their research on global prosperity and related issues.

Aims and Scope. GPrJ ournal is a multidisciplinary journal. We publish articles in all subject areas (except medical sciences).

Selection criteria. GPrJ ournal accepts previously unpublished and not submitted original articles that meet the J ournal's objectives and requirements. Papers may involve explanatory theory, empirical studies, policy studies or reviews.

Publication schedule. GPrJ ournal is published four times a year, on J anuary 25, April 25, July 25 and October 25.

Type of publication: electronic.

Language of publication: all languages.

Country of Publication: Czech Republic.

\title{
Publisher:
}

\section{Oktan Print (Czech Republic)}

5. května 1323/9, Praha 4, 140 oo.

https:// www.oktanprint.cz/

e-mail: oktanprint@email.cz

\section{Global Prosperity}

\author{
Volume 1 Issue 2
}

\section{1}

Date of Issue: 2021 July, 25

All journal content is licensed under a Creative Commons BY 4.0 International license 